\title{
Numerical analysis of the food web of an intertidal mudflat ecosystem on the Atlantic coast of France
}

\author{
Delphine Leguerrier ${ }^{1}$, Nathalie Niquil ${ }^{1, *}$, Nicolas Boileau ${ }^{2}$, Jadwiga Rzeznik ${ }^{1,3,4}$, \\ Pierre-Guy Sauriau ${ }^{5}$, Olivier Le Moine ${ }^{6}$, Cédric Bacher ${ }^{5}$ \\ ${ }^{1}$ Laboratoire de Biologie et Environnement Marins, EA 3168, Université de La Rochelle, Pôle Sciences et Technologie, \\ avenue Michel Crépeau, 17042 La Rochelle Cedex 1, France \\ ${ }^{2}$ Ligue pour la Protection des Oiseaux (LPO), Réserve Naturelle de Moëze-Oléron, Plaisance, 17708 Saint-Froult, France \\ ${ }^{3}$ ESA 8044 CNRS-BIM, Muséum National d'Histoire Naturelle, 57 rue Cuvier 75231 Paris, France \\ ${ }^{4}$ University of Gdansk, Institute of Oceanography, Marine Biology and Ecology Department, Al. Pilsudskiego 46, \\ 81-378 Gdynia, Poland \\ ${ }^{5}$ Centre de Recherche sur les Ecosystèmes Marins et Aquacoles (CREMA/UMR10 CNRS-IFREMER), BP 5, \\ 17137 L'Houmeau, France \\ ${ }^{6}$ Laboratoire Conchylicole Poitou-Charentes (LCPC), IFREMER, BP 133, 17390 La Tremblade, France
}

\begin{abstract}
Food web modelling is an ideal way to describe ecosystems, because it accounts for the totality of the relationships between its various components. One difficulty of such an approach, however, lies in the lack of data and information about some ecological relationships, resulting in underdefined systems. Inverse analysis can serve to complete steady-state food webs where the number of direct flow measurements is insufficient relative to the actual number of flows. We applied this method to the intertidal mudflat ecosystem of Brouage (eastern Marennes-Oléron Bay, SW France) and estimated the annual average carbon flows between the compartments of a coupled benthic and pelagic trophic food web from primary producers (microphytobenthos and phytoplankton) to top predators (fish and birds). The resulting network was very sensitive to the primary production of the microphytobenthos which was the most important flow in the system. Sensitivity analyses demonstrated the need for additional data on the nekton, pelagic protozoa, and bacterial compartments. The resulting network showed high bacterial activity, but indices resulting from network analysis showed low cycling in comparison with other ecosystems. The meiofauna had a small biomass, but constituted a very active compartment compared to the macrofauna. Bird production was limited by macrofaunal production. Macrofaunal production reached the maximum allowed by the analysis. The intertidal mudflat ecosystem at Brouage is dominated by benthic production (including benthic primary producers, secondary producers, and predators) with an input of phytoplankton primary production.
\end{abstract}

KEY WORDS: Carbon flow $\cdot$ Inverse analysis $\cdot$ Food web $\cdot$ Network analysis

\section{INTRODUCTION}

Marennes-Oléron Bay (MOB) is situated between the French Atlantic mainland and Oléron Island. It is the most important site for oyster production in Europe (Goulletquer \& Héral 1996) and it harbors a variety of other commercial activities, including fisheries and tourism. MOB is a macrotidal system, with a tidal range of $6 \mathrm{~m}$ during spring tides. It is influenced by continental inputs, mainly from the rivers Charente (Ravail et al. 1988, Soletchnik et al. 1998) and Gironde (Dechambenoy et al. 1977). A sector of MOB constitutes a bird reserve that has become since 1995 the major French landing site for shorebirds, with 45000 to 65000 birds in winter, and maybe 200000 ind. $\mathrm{yr}^{-1}$ (Deceunink 1997, Deceunink \& Maheo 1998; see also 
www.lpo-birdlife.asso.fr/etudes/wetlands/biblio. htm). According to Héral et al. (1989), the maximum carrying capacity of MOB (corresponding to an oyster production of $42500 \mathrm{t} \mathrm{yr}^{-1}$ ) has been attained; a shellfish culture has reached its carrying capacity when total bivalve biomass ceases to increase (Odum 1983 in Dame \& Prins 1998).

In the past, most ecological studies focussed on the oysters in MOB (Héral et al. 1989). Since the emergence of ecosystem management concepts such as sustainable development and nature conservation, research in the Bay has been extended to consider the entire ecosystem. The Brouage mudflat is situated on the eastern part of the bay along the mainland shore (Fig. 1). It is an important experimental site due to its exceptional morpho-sedimentological features (Bassoullet et al. 2000) and high primary productivity (Guarini et al. 1998), and it has become the best-studied mudflat of MOB. Pelagic and benthic habitats interact through physical processes such as sedimentation and resuspension which influence the behaviour of the organisms (Blanchard et al. 1998) and the trophic relationships between benthic and pelagic fauna. Nearly all the components of the Brouage ecosystem have been studied and, while not all of the communities have been formally described at the ecosystem level, usable information exists on most of the benthic and pelagic communities. However, no synthesis has been made between them to date, and there is no overall description of ecosystem functioning.

An ideal way to describe such an ecosystem is by simulating its trophic network to create an overview of its functioning. The functioning of an ecosystem can be investigated with the help of dynamic models (which are often limited by the need for a priori knowledge and by mathematical problems in solving large systems of differential equations) and of static models (which have the disadvantage of ignoring fluctuations over time). The technique of inverse analysis used in this study is designed to compensate for insufficiency of data on the ecosystem (Mercier 1986, Vézina \& Platt 1988, Vézina \& Pace 1994). It estimates unknown flows by assuming a steady state, and it incorporates various data such as measured flows, physiological rates and biomasses into the model.

We studied the average annual state of the Brouage intertidal mudflat ecosystem assuming that the system is in a steady state (i.e. there is no organic matter accumulation or loss in any compartment) using the inverse analysis method. To facilitate comparisons with other sites, we chose carbon as the unit of exchange between

compartments and we normalized calculated values to unit benthic surface area. Interpretation of the complex trophic network calculated by inverse analysis is based on techniques from network analysis and uses indices as defined in Ulanowicz $(1986,1997)$.

\section{MATERIALS AND METHODS}

Study site. The eastern part of MOB is divided into 2 large intertidal sectors. the southern one is the Brouage mudflat (Fig. 1) characterised by a gradual slope (1:1000) and a very large tidal area covered with prominent surface structures described as 'ridges and runnels' (Gouleau et al. 2000). Current speeds in the bay vary from 0.2 to $0.6 \mathrm{~m} \mathrm{~s}^{-1}$ (Bassoullet et al. 2000, Le Hir et al. 2000). Residual currents from river inputs flow from north to south in the bay (Bacher 1989).

Data and parameters. Results of local studies on the Brouage mudflat or the MOB were used whenever available. When no data were available, values from similar ecosystems (e.g. Wadden Sea and English Channel) were used as estimates. The compartments, associated data, and parameters of the model are compiled in Tables 1 to 4 .

Primary production: Microphytobenthic production rates were estimated on the basis of both experiments and models (Blanchard et al. 1997, Guarini et al. 1999). 
During daytime emersion periods the microalgae migrate to the surface of the sediment and only this surface biofilm is responsible for the primary production (Guarini et al. 1999). The seasonal rate $\mathrm{P}_{\max }$ (net production) used in the model (Table 2, Eq. 17) was measured on site (Blanchard et al. 1997). Between 30 and $70 \%$ of the biofilm biomass (137 to $319 \mathrm{~g} \mathrm{C} \mathrm{m}^{-2} \mathrm{yr}^{-1}$; Guarini pers. comm.) is resuspended during high tide, and the remainder sinks back into the sediment (Guarini et al. 2000) (Table 3, inequalities [Ineqs.] 1 \& 2).

In the water column, the average chl a concentration is equivalent to $0.66 \mathrm{mg} \mathrm{C}^{-1}$ (Sautour \& Castel 1993a, 1998). Turbidity is high in $\mathrm{MOB}$, so light penetration is reduced and phytoplankton production quickly decreases with increasing depth (Cloern 1987, Haney \&
Jackson 1996). However, low levels of light penetration do not preclude photosynthesis in the water column (Joint \& Pomroy 1981, 1993, Fichez et al. 1992, Shaw \& Purdie 2001). The net primary production was forced on the basis of values from the English Channel where the production/biomass rate (P/B) ranges from 30 to $40 \mathrm{yr}^{-1}$ (Ménesguen \& Hoch 1997; see Table 3, Ineqs. $3 \& 4$ ). We assumed that 5 to $30 \%$ of the net primary production is lost to respiration (Vézina \& Platt 1988; see Table 3, Ineqs. 5 to 8).

Benthic and pelagic bacteria: Garet (1996) estimated that the carbon biomass of benthic bacteria was $51 \%$ of the microphytobenthic biomass, and that it remained constant during the year. Benthic bacterial production varied from 41 to $51 \mathrm{yr}^{-1}$ (Table 3, Ineq. 14 \& 15). Res-

Table 1. Compartments of the Brouage food web. Biomass values were measured outside of the oyster farms, except for data on the 'cultivated oysters' compartment. Biomass data taken from other ecosystems are in parentheses; nd: not determined

\begin{tabular}{|c|c|c|c|}
\hline Compartment & Abbr. & Description & $\begin{array}{r}\text { Biomass } \\
\left(\mathrm{gC} \mathrm{m}^{-2}\right)\end{array}$ \\
\hline \multicolumn{4}{|l|}{ Terrestrial } \\
\hline Birds & $\mathrm{pbd}$ & Shorebirds + common shelducks & nd \\
\hline \multicolumn{4}{|l|}{ Benthic } \\
\hline Cultivated oysters & bco & Oyster farms cover $18 \%$ of the study site, biomass was measured at the farms & 21.1 \\
\hline Microphytobenthos & bph & Benthic primary producers & 3.8 \\
\hline Benthic detritus & bdt & Particulate organic matter & nd \\
\hline Benthic bacteria & $\mathrm{bbc}$ & Free or attached bacteria & 1.94 \\
\hline Meiofauna & bmi & Benthic organisms $(63 \mu \mathrm{m}-1 \mathrm{~mm})$ & 0.37 \\
\hline Predators & bpr & Omnivorous and carnivorous benthic macrofauna & 0.24 \\
\hline $\begin{array}{l}\text { Facultative suspension } \\
\text { feeders }\end{array}$ & bfs & 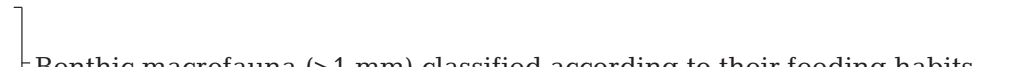 & 0.85 \\
\hline Deposit feeders & bdp & Benthic macrofauna (>1 mm) classified according to their feeding habits & 0.68 \\
\hline Suspension feeders & bff & ( & 0.08 \\
\hline \multicolumn{4}{|l|}{ Pelagic } \\
\hline Phytoplankton & pph & Pelagic primary producers and resuspended microphytobenthos & 2.54 \\
\hline Suspended detritus & pdt & & nd \\
\hline Pelagic bacteria & $\mathrm{pbc}$ & & $(0.10)$ \\
\hline Pelagic protozoa & $\mathrm{ppz}$ & $\begin{array}{l}\text { Heterotrophic flagellates, dinoflagellates, ciliates }(5-100 \mu \mathrm{m}) \\
\text { and microzooplankton }(<50 \mu \mathrm{m})\end{array}$ & $(0.11)$ \\
\hline Zooplankton & pzp & Microplankton (50 $\mu \mathrm{m}-1 \mathrm{~mm})$ and mesoplankton (1-5 mm) & 0.16 \\
\hline Nekton & pnk & Fishes, pelagic decapods and molluscs $>5 \mathrm{~mm}$ & nd \\
\hline
\end{tabular}

Table 2. Characteristics of linear equations used in inverse analysis of the Brouage food web. Eqs. (1) to (16) represent the system at equilibrium: in each compartment, total input equals total output. Eqs. (20) to (23) describe linear combinations of flows with null results. BM: Brouage Mudflat; MOB: Marennes-Oléron Bay; EC: English Channel; Pe: preliminary estimate

\begin{tabular}{|llll|}
\hline Equation no. & Compartment & Equation & Source \\
\hline 1 to 16 & All & Microphytobenthos & Mass equilibrium \\
17 & Zooplankton & Production $=372 \mathrm{~g} \mathrm{C} \mathrm{m}^{-2} \mathrm{yr}^{-1}$ & BM \\
18 & Zooplankton & Production $=$ biomass $56\left(\mathrm{yr}^{-1}\right)$ & $\mathrm{MOB}$ \\
19 & Pelagic bacteria & Respiration $=\mathrm{B} \times 112\left(\mathrm{yr}^{-1}\right)$ & $\mathrm{EC}$ \\
20 & Facultative suspension feeders & Production $=$ consumption $\times 0.31$ & EC \\
21 & Benthic predators & Pelagic consumption $=$ benthic consumption & Pe \\
22 & Birds & Consumption of oysters $=1 \%$ of oyster production & BM \\
23 & & Assimilation efficiency $=85 \%$ & Literature \\
\hline
\end{tabular}




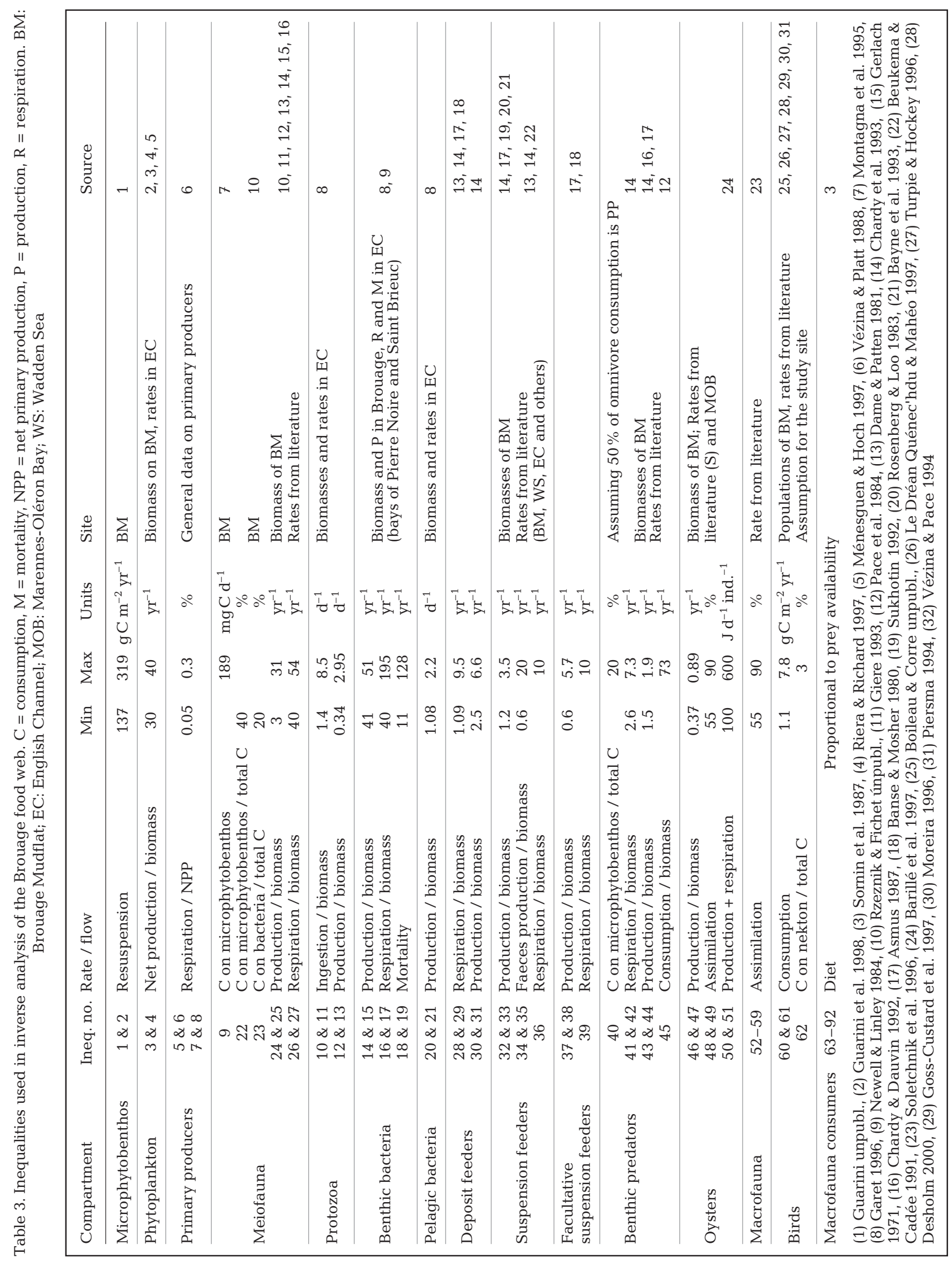


piration rates for benthic bacteria have been evaluated in the Bay of Saint-Brieuc, (France) (Chardy et al. 1993) and at the Pierre Noire station in the English Channel (Chardy \& Dauvin 1992) (Table 3, Ineqs. 16 to 19).

Pelagic bacterial production/consumption (P/C) rates have been measured in the English Channel (0.31; Newell \& Linley 1984); estimates of the P/B rate vary from 1.08 to $2.2 \mathrm{~d}^{-1}$ (Linley et al. 1983, Newell \& Field 1983, Fuhrman \& Azam 1982) (Table 3, Ineq. 20 \& 21).

Pelagic secondary producers (protozoa and zooplankton): Heterotrophic protozoa are a trophic intermediary between bacteria and oysters but have not been studied quantitatively in MOB (Le Gall et al. 1997,
Dupuy et al. 1999, 2000). Thus, concentration data measured in the English Channel (Newell \& Linley 1984) are used instead. The ingestion/biomass rates for the protozoa were measured for Noctiluca miliaris (Dewey 1976 in Newell \& Linley 1984) (Table 3, Ineq. 10 \& 11) and $\mathrm{P} / \mathrm{B}$ rates were from heterotrophic bacterivorous flagellates (Newell \& Linley 1984) (Table 3, Ineq. 12 \& 13).

Euterpina acutifrons is the major component of the zooplankton community in $\mathrm{MOB}$; zooplankton production values were averaged after Sautour \& Castel (1993a,b, 1998; Table 2, Eq. 18). Respiratory rates (Table 2, Eq. 19) were from values calculated for the English Channel (Newell \& Linley 1984).

Meiofauna: Of the intertidal benthic meiofauna on the Brouage mudflat 95\% are nematodes, among which Metachromadoroides, Ptycholaimellus, Sabatieria and Tershellingia make up $57 \%$ of the total (Rzeznik et al. unpubl.). Observations from a study on the influence of oyster beds on species assemblages in Arcachon Bay, France (Castel et al. 1989) were used to estimate the meiofauna biomass per $\mathrm{m}^{2}$ under oyster beds. The meiofauna consisted of $20 \%$ strict bacterivores and $45 \%$ strict herbivores (Reznik et al. unpubl.), and these feeding habits were used as forcing functions (Table 3, Ineqs. 22 \& 23). Consumption of microphytobenthos by meiofauna at Brouage ranges from 58 to $189 \mathrm{mgC}$ $\mathrm{m}^{-2} \mathrm{~d}^{-1}$ during springtime (Montagna et al. 1995), when it is probably at a maximum (Table 3, Ineq. 9). P/B rates vary in the literature from 3 to $31 \mathrm{yr}^{-1}$ for muddy substrates (Giere 1993) (Table 3, Ineqs. 24 \& 25). Respiration/biomass rates vary from 40 to $54 \mathrm{yr}^{-1}$ (Dame \& Patten 1981, Pace et al. 1984, Chardy \& Dauvin 1992, Chardy et al. 1993, Giere 1993) (Table 3, Ineqs. 26 \& 27).

Benthic macrofauna: Macrofauna were divided into 4 compartments according to trophic regime (Table 4). The gastropod Hydrobia ulvae and the bivalves Scrobicularia plana, Abra nitida, and Macoma balthica are the most abundant species on the mudflats. The non-cultivated macrofaunal biomass was evaluated in MOB in 1985 (Sauriau 1987, Sauriau et al. 1989), and again in 1995 on the Brouage mudflat outside the oyster 
cultures (Kang 1999, Table 4). A correction was applied to the latter values to calculate a weighted mean biomass per average $\mathrm{m}^{2}$ taking into account that $16 \%$ of the surface is occupied by oyster farms. At steady state, consumption equals pseudo-faeces production plus faeces production plus respiration plus tissue production. Pseudo-faeces production does not appear in the present model because it does not participate in the carrying capacity, so we only take ingestion into account in the present model.

Nekton: The main species on the Brouage mudflat are: Solea vulgaris (405 t sold in 2001 in La Cotinière Harbour), Crangon crangon (30 t), Merlangius merlangus (180 t), Dicentrarchus labrax (181 t), Sepia officinalis (441 t), Mullus surmuletus (76 t), Alloteuthis and Liza ramada (33 t) (Nadeau pers. comm.). There are few quantitative biomass and production data on the pelagic macrofauna. The only numerical values are from local reports (on the 'Pertuis d'Antioche', Guérault et al. 1996; and on coastal nurseries, Guérault \& Désaunay 2001) and cannot be extrapolated to the Brouage mudflat, particularly in the case of juvenile fish.

Birds: Shorebirds consume large portions of a region's annual macrofauna production (Baird \& Milne 1981, Baird et al. 1985) and may negatively impact local invertebrate populations. At Brouage they have become increasingly numerous since the establishment of a bird sanctuary. The main species on the mudflat are dunlins Calidris alpina, and knots C. canutus; these 2 species represent $68 \%$ of the total number of birds feeding on the mudflat. Their food consumption was evaluated on the basis of physiological rates found in the literature (Piersma \& Davidson 1992a,b, Moreira 1996, Turpie \& Hockey 1996) (Table 3, Ineqs. $60 \& 61$ ).

Inverse analysis and flow estimates. Trophic-web inverse analysis (Vézina \& Platt 1988, Vézina 1989) is a numerical method for developing complete, steadystate food-web models. The method uses field estimates and other data sources as input to a network of equations and inequalities in order to build the best estimates of food-web flows. The solution selected is the minimum of a norm ('parsimony principle'). Descriptions of the method and the equations used are given in Appendix 1. The algorithm of resolution from Vézina \& Platt (1988) was programmed by G. A. Jackson using the software Matlab $^{\odot}$.

Benthic and pelagic systems are strongly coupled in intertidal ecosystems such as the Brouage mudflats, and with our approach the inverse analysis method can be applied to both systems in the same model. The conceptual model consists of 16 compartments (Table 1): 2 non-living factors (benthic and suspended detritus), and 14 categories of organisms. The choice of aggregation level for the compartments was based on size class, habitat (benthic/pelagic), and feeding behaviour. In this study, the term 'detritus' refers to dissolved and particulate organic carbon, aggregated into a single compartment in each compartment (benthic or pelagic).

Inputs (Table 5) consist of 2 types of primary production (phytoplanktonic and microphytobenthic) plus the suspended detritus supplied by rivers and tidal currents. Carbon exports (Table 5) included: respiratory losses, material exports (human consumption of oysters, fish and bird production, advection of suspended detritus), and burial. The quantitatively non-negligible flows linking the compartments are determined on the basis of the animals' biology, feeding habits, and habitats (Table 6). The flow values for the Brouage mudflat are reported in Tables $5 \& 6$.

Sensitivity analysis. Sensitivity analyses were conducted to assess the robustness of the solution to changes in the data and to constraints. Biomass and other data (including results of equations and inequalities) were varied by $\pm 10 \%$ and the inverse analysis

Table 5. Inputs and outputs in the coupled benthic-pelagic system of the Brouage food web (numerical results of inverse analysis). A priori flows are indicated by flow numbers corresponding to the sensitivity analyses (see Figs. 4 \& 5)

\begin{tabular}{|c|c|c|}
\hline & $\begin{array}{l}\text { Flow } \\
\text { no. }\end{array}$ & $\begin{array}{l}\text { Flow values } \\
\left(\mathrm{g} \mathrm{C} \mathrm{m}^{-2} \mathrm{yr}^{-1}\right)\end{array}$ \\
\hline \multicolumn{3}{|l|}{ Inputs } \\
\hline Microphytobenthos & 1 & 391 \\
\hline Phytoplankton & 2 & 75 \\
\hline Suspended detritus & 3 & 0 \\
\hline Total & & 466 \\
\hline \multicolumn{3}{|l|}{ Exports } \\
\hline Phytoplankton & 76 & 63 \\
\hline Benthic detritus & 77 & 26 \\
\hline Suspended detritus & 78 & 17 \\
\hline Cultured oysters & 79 & 3.3 \\
\hline Nekton & 80 & 46 \\
\hline Birds & 81 & 1.3 \\
\hline Total & & 156.6 \\
\hline \multicolumn{3}{|l|}{ Respiration } \\
\hline Microphytobenthos & 82 & 18.6 \\
\hline Phytoplankton & 83 & 3.6 \\
\hline Benthic bacteria & 84 & 79.0 \\
\hline Pelagic bacteria & 85 & 53.7 \\
\hline Meiofauna & 86 & 29.7 \\
\hline Pelagic protozoa & 87 & 31.4 \\
\hline Zooplankton & 88 & 18 \\
\hline Deposit feeders & 89 & 5.5 \\
\hline Facultative suspension feeders & 90 & 7 \\
\hline Suspension feeders & 91 & 0.8 \\
\hline Cultured oysters & 92 & 12.8 \\
\hline Benthic predators & 93 & 1.8 \\
\hline Nekton & 94 & 45.9 \\
\hline Birds & 95 & 1.3 \\
\hline Total & & 309.1 \\
\hline
\end{tabular}


was recalculated. We evaluated the equations for microphytobenthic production, zooplankton production, and zooplankton respiration, as the remaining equations were combinations of flows with a null result. The sensitivity of the results to elevated biomasses were also investigated. The most influential biomasses, equations, and inequalities were determined on the basis of the scope (number of varied flows), and intensity (average variation of flows) of their influence.

Network analysis. The 'Netwrk $4.2^{\prime} \odot$ program (Ulanowicz 1999: www.cbl.umces.edu/ ulan/) was used for calculation of network analysis indices of the food web derived from inverse analysis. The vector of every flow

Table 6. Numerical results of inverse analysis of the Brouage food web (internal flows in $\mathrm{gC} \mathrm{m}^{-2} \mathrm{yr}^{-1}$ ). From = compartment of origin; To = destination compartment; Flow no. $=a$ priori flows from sensitivity analyses in Figs. $4 \& 5$. See Table 1 for abbreviations

\begin{tabular}{|c|c|c|c|c|c|c|c|}
\hline From & & To & Flow no. & From & & Го & Flow no. \\
\hline \multirow[t]{7}{*}{ bph 391} & pph & 136.88 & 4 & \multirow[t]{3}{*}{ bmi 100} & bdt & 53.53 & 42 \\
\hline & bdt & 101.03 & 5 & & bpr & 0.00 & 43 \\
\hline & bmi & 47.51 & 6 & & pnk & 17.04 & 44 \\
\hline & bdp & 4.16 & 7 & \multirow[t]{4}{*}{ ppz 58} & pdt & 13.90 & 45 \\
\hline & bfs & 1.64 & 8 & & pup & 13.10 & 46 \\
\hline & bpr & 0.00 & 9 & & bfs & 0.00 & 47 \\
\hline & pnk & 81.24 & 10 & & bff & 0.00 & 48 \\
\hline \multirow[t]{7}{*}{ pph 211} & pdt & 45.06 & 11 & & bco & 0.00 & 49 \\
\hline & ppz & 31.17 & 12 & \multirow[t]{6}{*}{ pzp 43} & pdt & 15.58 & 50 \\
\hline & pzp & 29.49 & 13 & & bfs & 0.00 & 51 \\
\hline & bfs & 6.25 & 14 & & bff & 0.00 & 52 \\
\hline & bff & 1.84 & 15 & & bco & 3.63 & 53 \\
\hline & bco & 14.90 & 16 & & bpr & 0.00 & 54 \\
\hline & pnk & 16.64 & 17 & & pnk & 5.37 & 55 \\
\hline \multirow[t]{6}{*}{ bdt 205} & pdt & 8.63 & 18 & \multirow[t]{4}{*}{ bdp 14} & bdt & 6.10 & 56 \\
\hline & $\mathrm{bbc}$ & 170.43 & 19 & & bpr & 0.93 & 57 \\
\hline & bmi & 0.00 & 20 & & pnk & 0.00 & 58 \\
\hline & bdp & 0.00 & 21 & & pbd & 1.07 & 59 \\
\hline & bfs & 0.00 & 22 & \multirow{4}{*}{ bfs 17} & bdt & 7.67 & 60 \\
\hline & pnk & 0.00 & 23 & & bor & $\begin{array}{l}t .0 t \\
1.12\end{array}$ & $\begin{array}{l}60 \\
61\end{array}$ \\
\hline \multirow[t]{8}{*}{ pdt 148} & bdt & 0.00 & 24 & & pnk & 0.00 & 62 \\
\hline & $\mathrm{pbc}$ & 130.35 & 25 & & pbd & 1.30 & 63 \\
\hline & $\mathrm{ppz}$ & 0.00 & 26 & \multirow{5}{*}{ bff 1.8} & bdt & 083 & 64 \\
\hline & pzp & 0.00 & 27 & & Dat & $\begin{array}{l}0.03 \\
0.12\end{array}$ & $\begin{array}{l}04 \\
65\end{array}$ \\
\hline & bfs & 0.00 & 28 & & bpr & 0.12 & $\begin{array}{l}65 \\
66\end{array}$ \\
\hline & bff & 0.00 & 29 & & pnk & 0.00 & $\begin{array}{l}66 \\
67\end{array}$ \\
\hline & bco & 0.00 & 30 & & pbd & & \\
\hline & pnk & 0.00 & 31 & \multirow[t]{2}{*}{ bco 29.45} & bdt & 13.25 & 68 \\
\hline \multirow[t]{5}{*}{ bbc 170} & bdt & 22.04 & 32 & & bpr & 0.03 & 69 \\
\hline & bmi & 52.75 & 33 & \multirow[t]{3}{*}{ bpr 2.5} & bdt & 0.25 & 70 \\
\hline & bdp & 9.40 & 34 & & pnk & 0.00 & 71 \\
\hline & bfs & 6.88 & 35 & & pbd & 0.44 & 72 \\
\hline & bpr & 0.32 & 36 & \multirow[t]{2}{*}{ pnk 120} & pbd & 0.09 & 73 \\
\hline \multirow[t]{5}{*}{ pbc 130} & pdt & 36.24 & 37 & & pdt & 28.42 & 74 \\
\hline & ppz & 27.20 & 38 & \multirow[t]{4}{*}{ pbd 3.0} & \multirow[t]{4}{*}{ bdt } & \multirow[t]{4}{*}{0.46} & \multirow[t]{4}{*}{75} \\
\hline & bfs & 2.28 & 39 & & & & \\
\hline & bff & 0.00 & 40 & & & & \\
\hline & bco & 10.93 & 41 & & & & \\
\hline
\end{tabular}

is composed of 4 parts: input, export, respiration, and internal flows. The flux of matter through a compartment is its individual throughput. Since the system is at equilibrium, throughput is either equal to the sum of inputs to a compartment or the sum of the outputs from a compartment. The throughput quantifies the relative activity of each compartment in the system, and the Total System Throughput (TST), i.e. the sum of all flows, is an indicator of ecosystem activity (Ulanowicz 1986). The cycling throughput of each compartment is the quantity of carbon that cycles through the individual compartments and is a measure of its participation in the cycling of carbon through the ecosystem. The cycling activity of a compartment is defined as the fraction of its throughput involved in cycling (Fasham 1985) and is considered to be a measure of its dependence on the carbon cycling in the ecosystem. The Finn cycling index (FCI) (Finn 1976) represents the proportion of the carbon flows involved in cycling for the whole system.

Coupling the benthic and pelagic systems. Separate pelagic and benthic food webs were constructed to assess the linking of the benthic and pelagic systems in the same inverse analysis computation and to test the usefulness of having a food web model on one particular zone of the MOB. We constructed the benthic and pelagic subsystems in 2 ways: (1) we extracted the expected values of hypothetical benthic and pelagic subsystems from the 'coupled' result, and (2) we computed an inverse analysis on 2 systems separated a priori. The benthic conceptual model consisted of 10 compartments (microphytobenthos, benthic detritus, benthic bacteria, meiofauna, deposit feeders, facultative suspension feeders, suspension feeders, cultured oysters, benthic predators, and birds) and 55 a priori flows linked by 24 equations and 51 inequalities. The pelagic conceptual model consisted of 7 compartments (phytoplankton, suspended detritus, pelagic bacteria, pelagic protozoa, zooplankton, nekton and birds) and 34 a priori flows linked by 12 equations and 13 inequalities. The network analysis was repeated on each of the 4 food webs ( 2 from the 'coupled result' and 2 from a priori separated systems) for comparison. 


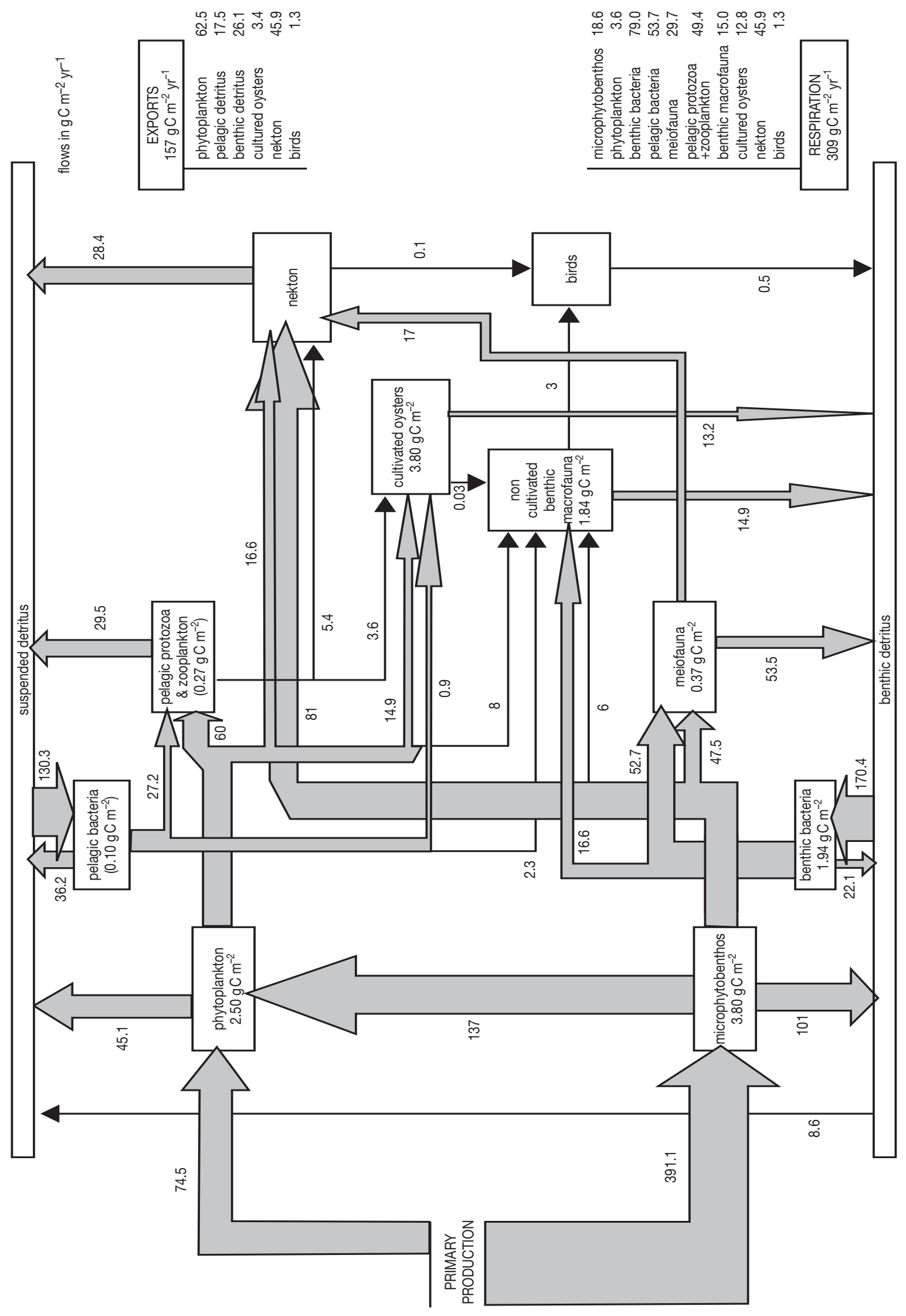

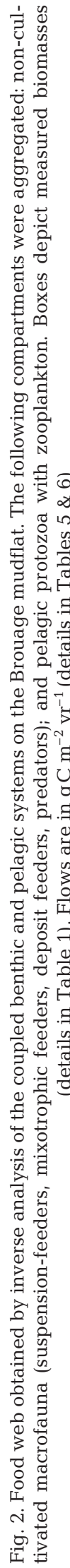




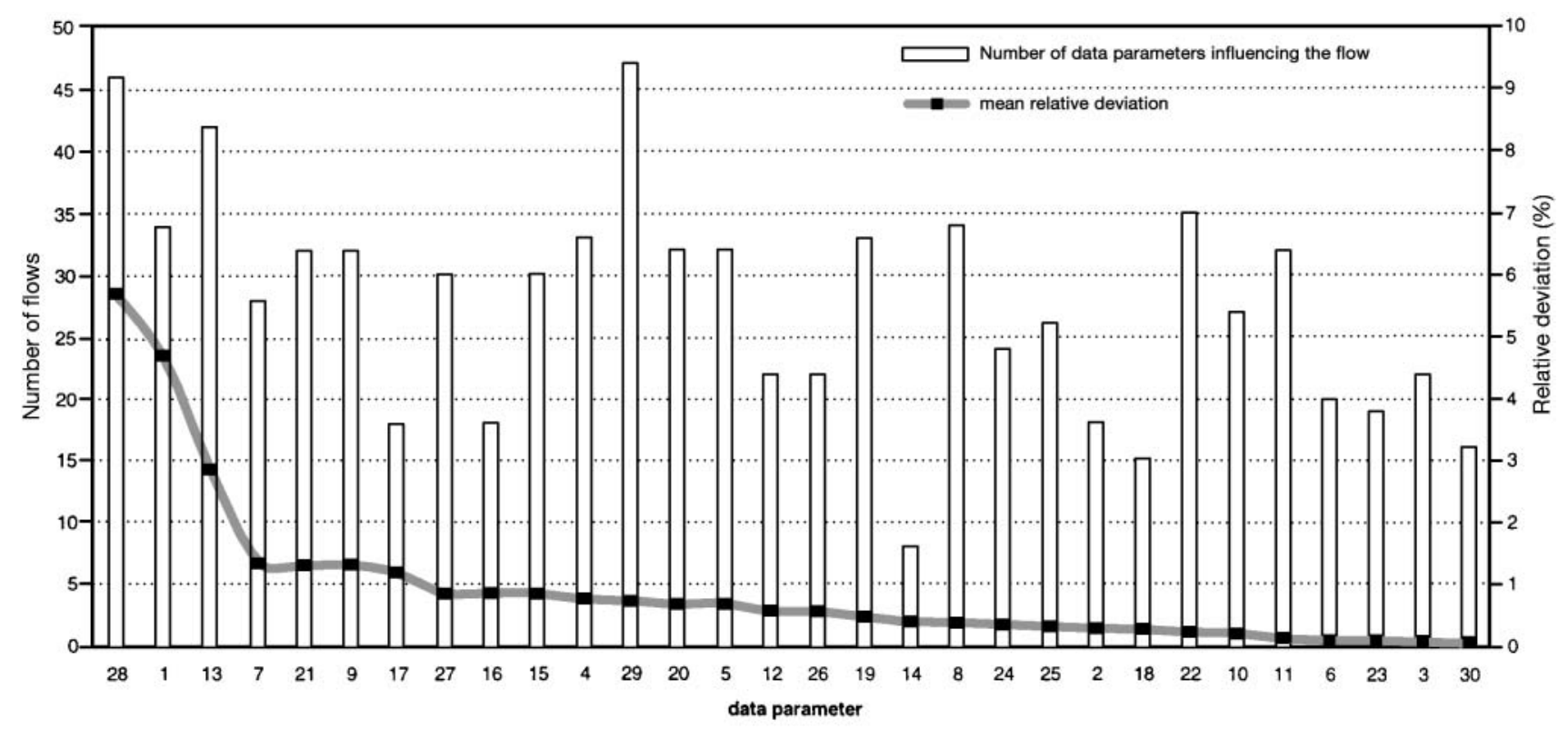

Fig. 3. Influence of a $10 \%$ variation in the data on the result of inverse analysis of the Brouage food web (number of flows influenced, and mean deviation induced). Equation parameters: (1) production of microphytobenthos, (2) production of zooplankton, (3) respiration of zooplankton. Inequality parameters: (4) minimal resuspension of microphytobenthos, (5) minimal production of phytoplankton, (6) minimal production of pelagic protozoa, (7) minimal production of benthic bacteria, (8) minimal respiration of benthic bacteria, (9) minimal production of pelagic bacteria, (10) maximum production of meiofauna, (11) maximum respiration of meiofauna, (12) maximum respiration of deposit feeders, (13) maximum production of suspension feeders, (14) maximum respiration of suspension feeders, (15) maximum respiration of facultative suspension feeders, (16) maximum respiration of predators, (17) maximum production of predators, (18) maximum production of oysters, (19) maximum metabolism of oysters. Biomass parameters: (20) phytoplankton, (21) pelagic bacteria, (22) benthic bacteria, (23) pelagic protozoa, (24) zooplankton, (25) meiofauna, (26) deposit feeders, (27) facultative suspension feeders, (28) suspension feeders, (29) oysters, (30) predators

\section{RESULTS}

\section{Annual food web model}

The modelled trophic network had a total primary production of $466 \mathrm{gC} \mathrm{m}^{-2} \mathrm{yr}^{-1}$, of which $84 \%$ was by microphytobenthos and $16 \%$ by phytoplankton (Fig. 2, Table 5). There was no import of detritus. The exports amounted to $157 \mathrm{~g} \mathrm{C} \mathrm{m}^{-2} \mathrm{yr}^{-1}$, which was $34 \%$ of the total output. The most important exports were those of phytoplankton and suspended microphytobenthos ( $40 \%$ of exports), nekton $(29 \%)$ and the burial of benthic detritus $(17 \%)$. The export of material via suspended detritus was less $(11 \%)$. The exported oyster and bird production were relatively small ( 2 and $0.8 \%$, respectively). The total respiratory loss of the system was twice as high as the material exports (Table 5).

The internal flows were all associated with consumption, detritus formation, or resuspension (Table 6). The 9 largest flows were: benthic and planktonic bacteria consuming detritus (170 and $130 \mathrm{gC} \mathrm{m}^{-2} \mathrm{yr}^{-1}$, respectively), resuspension of microphytobenthos (136 gC $\left.\mathrm{m}^{-2} \mathrm{yr}^{-1}\right)$, microphytobenthos created benthic detritus (101 $\left.\mathrm{g} \mathrm{C} \mathrm{m}^{-2} \mathrm{yr}^{-1}\right)$, nekton consuming microphytobenthos $\left(81 \mathrm{gC} \mathrm{m}^{-2} \mathrm{yr}^{-1}\right)$, benthic and pelagic bacterial respiration (79 and $54 \mathrm{gC} \mathrm{m}^{-2} \mathrm{yr}^{-1}$ ), and meiofauna consumption of benthic bacteria $\left(53 \mathrm{gC} \mathrm{m}^{-2} \mathrm{yr}^{-1}\right)$ and egestion to detritus $\left(54 \mathrm{gC} \mathrm{m}^{-2} \mathrm{yr}^{-1}\right)$.

Of the allowed 95 flows in the conceptual model, 25 equalled zero. Although detritus utilization by organisms other than bacteria (protozoa, zooplankton, macrofauna, nekton, meiofauna) was allowed, it did not occur in this system. According to the model, suspension feeders did not ingest protozoa, bacteria, or zooplankton, but ingested exclusively phytoplankton and microphytobenthos. Nekton did not feed on benthic macrofauna in the final result.

\section{Sensitivity analyses}

Among the most influential parameters (Fig. 3), in terms of relative amount of variation produced, were the suspension feeders (biomass and production, nos. 28 and 13), the microphytobenthos production (no. 1), the minimal benthic bacterial production (no. 7), the minimal pelagic bacterial production (no. 9) and the pelagic bacterial biomass (no. 21). Some of the most affected flows (Fig. 4) were those linked to: nekton consumption of primary producers and of zooplankton, 


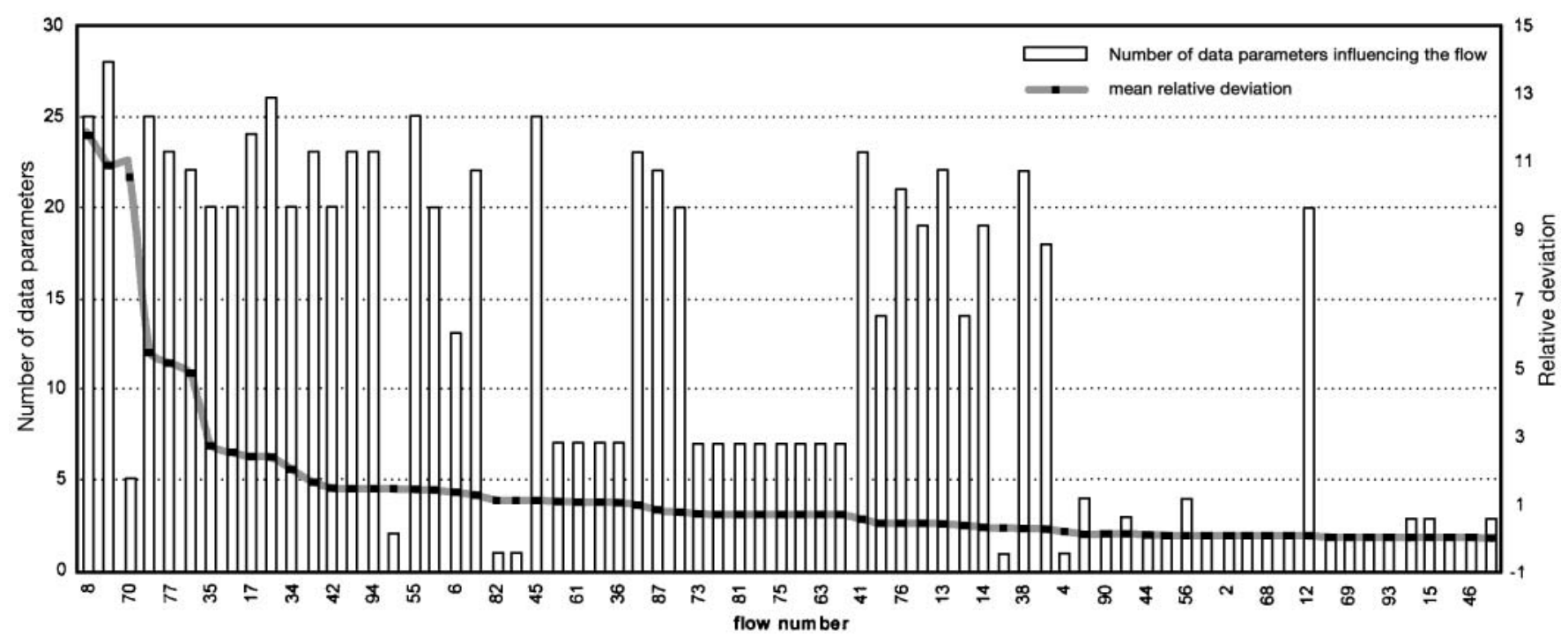

Fig. 4. Flows impacted by a $10 \%$ variation in the data for sensitivity analysis of the Brouage food web (number of data influencing each flow by more than $10 \%$, and mean deviation induced). Flow numbers are listed in Tables 5 \& 6

exportation of material and respiration (nos. 10, 17, 55, 80 \& 94), diet of facultative deposit feeders (nos. 8, 35 \& 39), consumption of microphytobenthos (nos. 5 to 10), and flows involving benthic and suspended detritus (nos. 18, 70, 77, 78, 50, 42 \& 5).

In absolute values, nekton production was the most sensitive of the 3 types of production in the system (Fig. 5). The flows in the nekton compartment were not constrained by data or direct inequalities. Bird production was influenced by data on filter feeders and benthic predators. Oyster production was only influenced by the variables that described them directly (oyster biomass and maximal production).
Sensitivity analysis showed that enhancing zooplankton respiration or production had very weak consequences for the system, in comparison to the effect of a $10 \%$ increase in microphytobenthic production. This increase had no influence on macrofaunal production (nos. 56 to 72), even though their diet would have changed. As a whole, 23 flows were changed, i.e. $33 \%$ of the non-null flows.

Sensitivity analysis of the inequalities showed that the most influential ones were: microphytobenthos resuspension (parameter 4) and maximal metabolism of cultivated oysters (no. 19) (Fig. 3). The maximal respiration and production of predators (nos. $16 \& 17)$ and

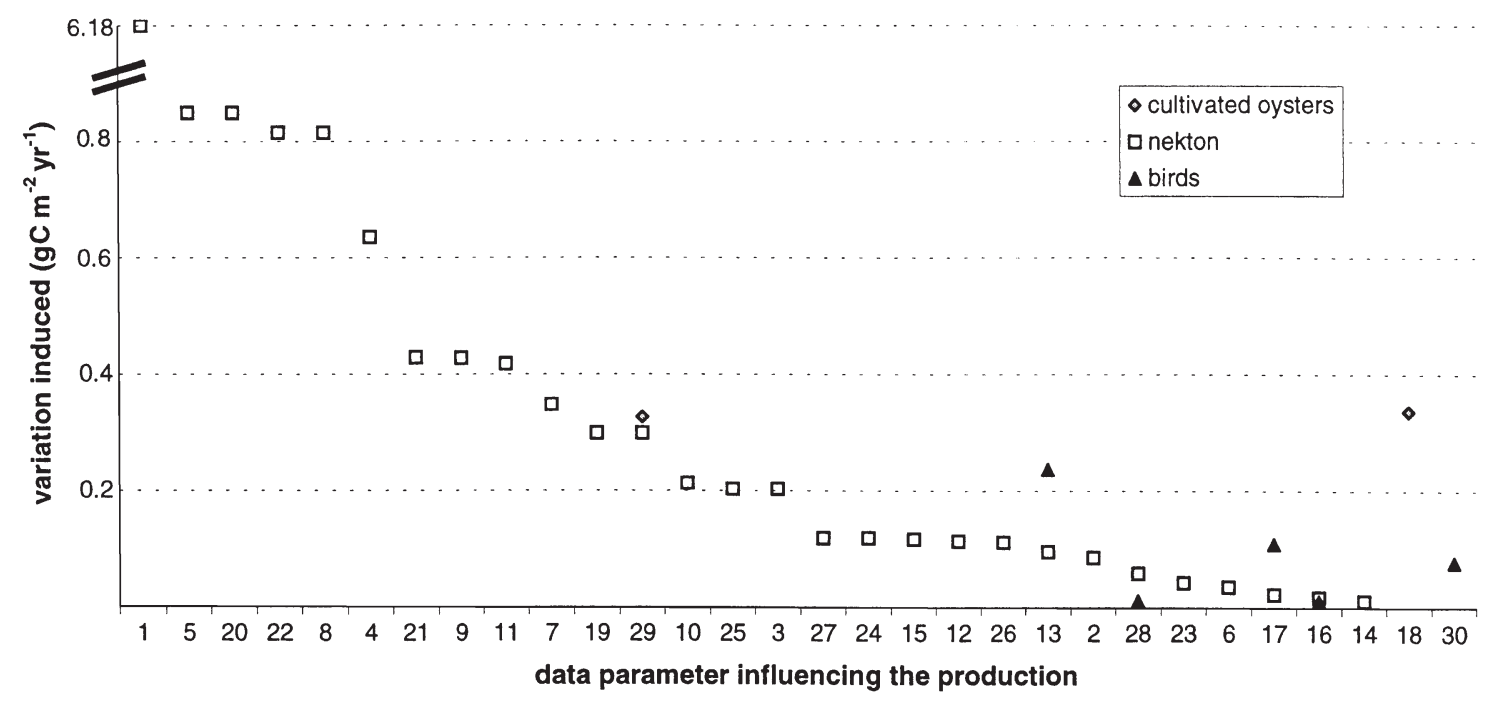

Fig. 5. Influence of data parameters on the variation of exports of $\mathrm{C}$ from the compartments for cultivated oysters, nekton, and birds in the Brouage food web. Parameters are the same as in Fig. 3 


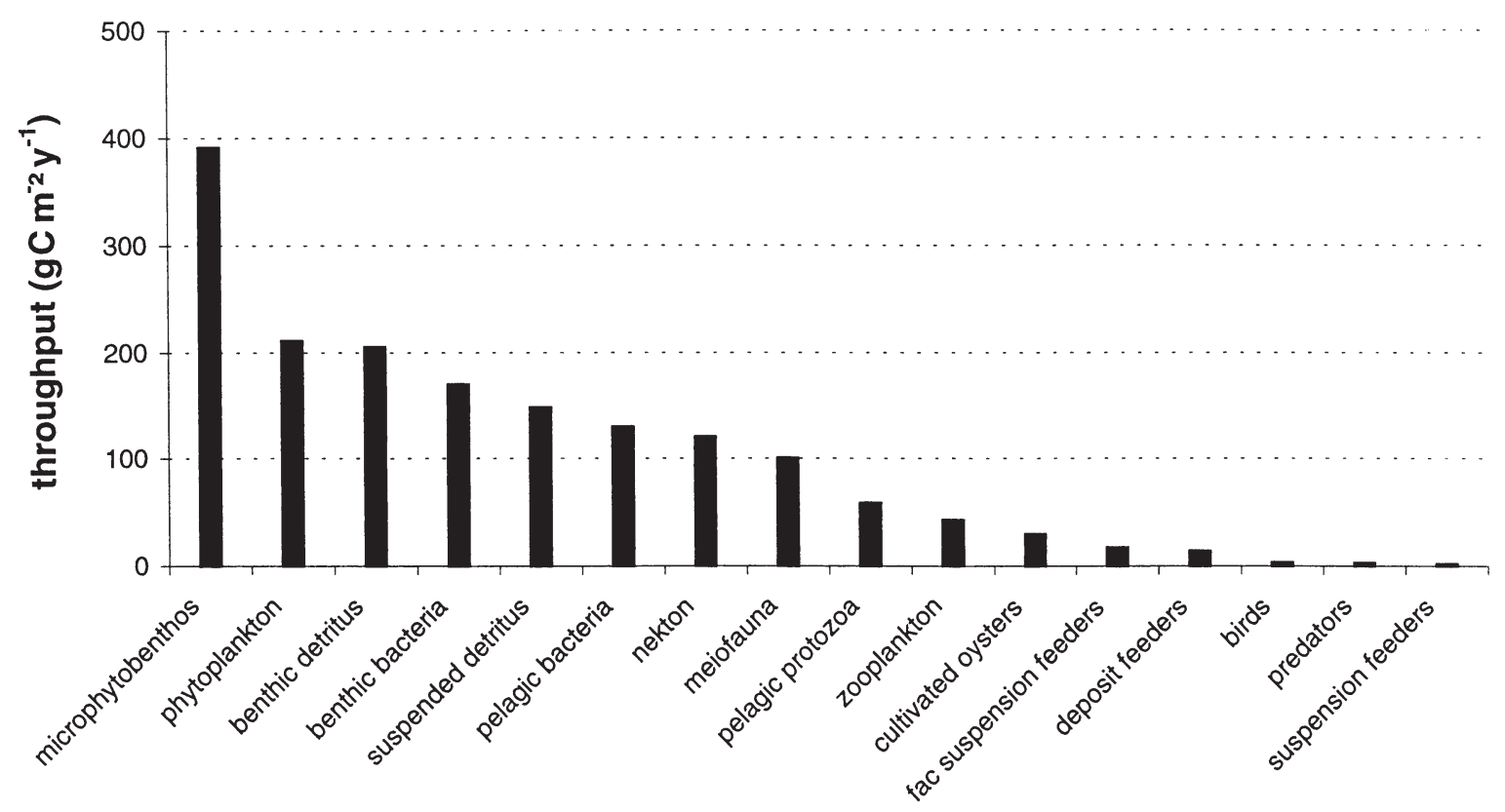

Fig. 6. Compartmental throughputs in the Brouage food web (amount of material entering or exiting the compartment during one year). Data from Table 5

the maximal production of suspension feeders (parameter 13) had an influence on macrofauna, nekton and bird productions (Fig. 5). In contrast, the flows most subject to influences were: consumption of microphytobenthos by the meiofauna (no. 6), resuspension of benthic detritus (no. 18), flows linked to the nekton (production of detritus, export and respiration) (nos. $10,17,55,74,80 \& 94)$ and advection or sedimentation of detritus (nos. $77 \& 78$ ), which were influenced by all inequalities (results not shown).

The flows that were influenced most by biomasses were: resuspension of benthic detritus (no. 4), export of detritus (nos. $77 \&$ 78), all flows linked to the nekton (nos. 10, 17, 55, 74, 80 \& 94), consumption of zooplankton by oysters (no. 53), and consumption of microphytobenthos by facultative deposit feeders (no. 8).

\section{Network analysis}

The total system throughput was $2111 \mathrm{~g} \mathrm{C} \mathrm{m}^{-2} \mathrm{yr}^{-1}$. Primary producers had the most important throughput (Fig. 6), with a predominance of benthic over pelagic primary producers. Benthic detritus and benthic bacteria had a greater throughput than suspended detritus and pelagic bacteria. Meiofauna and nekton made an important contribution, higher than protozoa or zooplankton. The total macrofauna (cultivated or uncultivated) throughput was $65 \mathrm{~g} \mathrm{C} \mathrm{m}^{-2} \mathrm{yr}^{-1}$.

Among the 37 pathways of carbon cycling, 20 involved both benthic and suspended detritus, 4 involved sus- pended detritus only, and 13 involved benthic detritus only. Carbon cycled mainly through the benthic and suspended detritus, benthic and pelagic bacteria, meiofauna, protozoa, and zooplankton (Fig. 7). Nearly onethird $(29 \%)$ of the benthic detritus and bacterial throughputs were involved in cycling: 58 and $48 \mathrm{~g} \mathrm{C} \mathrm{m}^{-2}$ $\mathrm{yr}^{-1}$, respectively. For the suspended detritus and bacterial throughputs, $31 \%$ of the throughputs (46 and $40 \mathrm{~g} \mathrm{C} \mathrm{m}^{-2} \mathrm{yr}^{-1}$ ) were involved in cycling. The cycling activity of the cultivated oysters and nekton was $0.4 \%$ and $0.3 \%$ of their throughputs, respectively. Of the total flows of carbon through the food web, $21 \%$ (Finn Cycling Index) participated in cycling pathways (Table 7).

\section{Coupling the benthic and pelagic systems}

Out of 33 possible flows for the pelagic system, 7 were zero in the non-coupled computation (instead of 3 expected from the coupled computation), 21 flows were smaller than expected and 11 were greater, with a mean $172 \%$ decrease. Among the 55 possible flows for the benthic system, 12 were null and 1 flow expected to be null was positive; 20 flows were smaller than expected and 14 greater, with a mean 15.5\% decrease. All the expected cycles were obtained with separated computations (Table 7). Both benthic and pelagic FCI were higher than expected from the coupled system (19 and 38 vs 18 and 17\%). The values for the inputs and outflows of the coupled systems were greater than values obtained by modelling each 


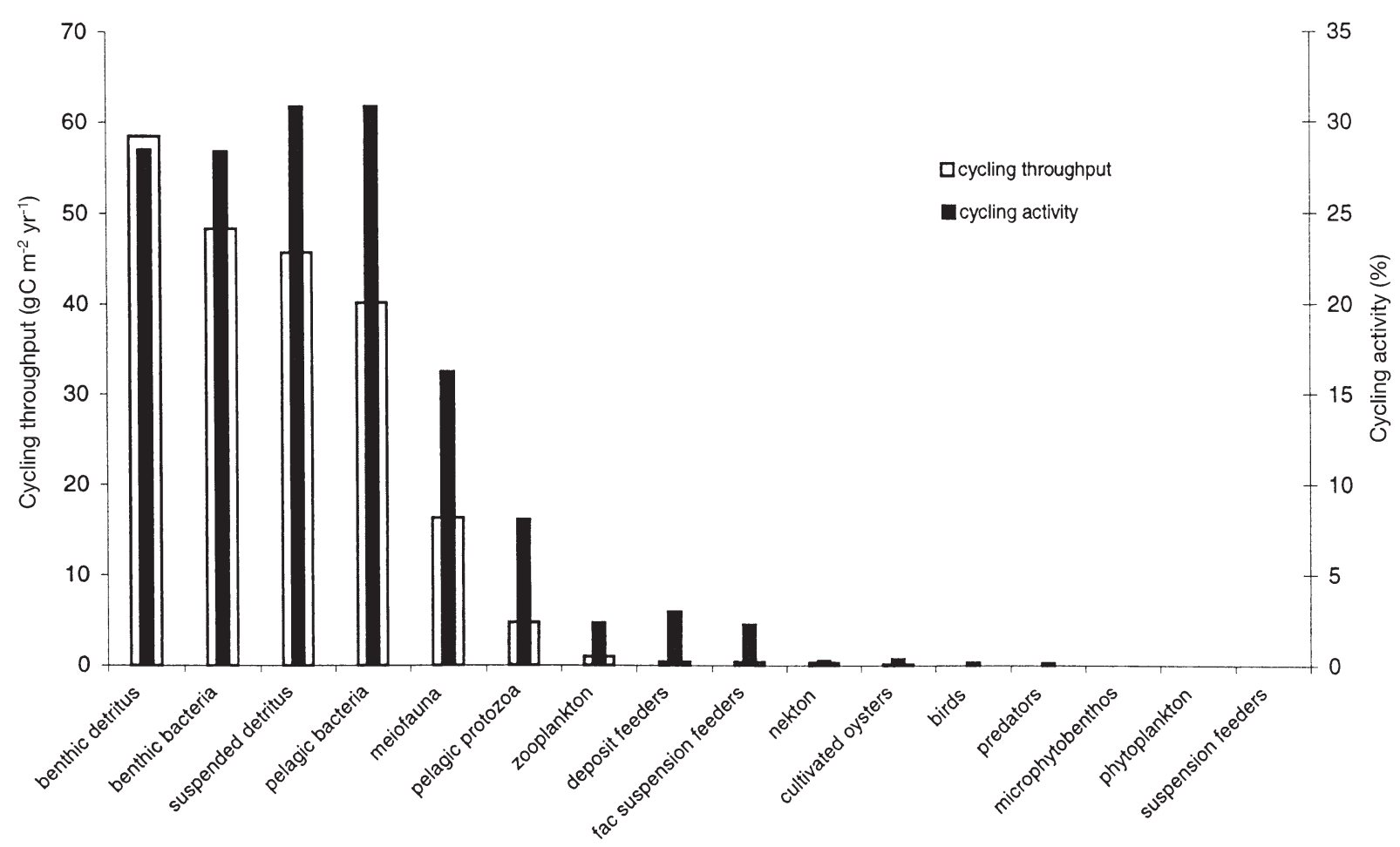

Fig. 7. Cycling throughput (contribution of the compartment to the cycling activity of the entire system) and cycling activity (fraction of the compartment throughput involved) for each compartment in the Brouage food web. Cycling throughput represents the importance of the compartment for the cycling in the system, and the cycling activity represents the importance of cycling for the compartment

system separately. This difference was greater for the pelagic system (Table 7).

\section{DISCUSSION}

We characterized the properties and functioning of the Brouage Mudflat ecosystem by computing an inverse analysis using a consistent and unified approach based on all the available compartmental information. variations are balanced over the course of an average year. Therefore, we assume that the system is at equilibrium. The 2 most important invasive species in MOB (Crepidula fornicata: Deslous-Paoli et al. 1983, Sauriau et al. 1998; and Ocinebrellus inornatus: Pigeot et al. 2000) were poorly represented on the Brouage mudflat; only small patches exist under oyster beds in the south-western part.

Our second assumption was the parsimony principle, a mathematical criterion (here, the least squares condi-

\section{Methodological choices}

We describe the trophic network over a whole year, because such a time period averages seasonal blooms and most populations have the same patterns year after year (Hily 1976, Sauriau 1987, Sauriau et al. 1989, Sauriau \& Bacher 1991, Kang, 1999). Studies in other European estuaries have shown that some species decline or increase in abundance over the course of a year (Desprez et al. 1991, Essink et al. 1991); however, the small
Table 7. Network analyses of the benthic and pelagic systems of the Brouage food web. Coupled: calculation based on the coupled system (far right column); non coupled: results of inverse analysis of the separate systems. Coupled system flows are shown in Tables 5 \& 6

\begin{tabular}{|lrrrrrr|}
\hline \multirow{2}{*}{ Estimates } & \multicolumn{2}{c}{ Benthic } & & \multicolumn{2}{c}{ Pelagic } & \multirow{2}{*}{ Total } \\
& Coupled & $\begin{array}{c}\text { Non- } \\
\text { coupled }\end{array}$ & Coupled & $\begin{array}{c}\text { Non- } \\
\text { coupled }\end{array}$ & coupled \\
& & & & & & \\
\hline Total inputs $\left(\mathrm{g} \mathrm{C} \mathrm{m}^{-2} \mathrm{yr}^{-1}\right)$ & 431 & 404 & 321 & 93 & 466 \\
Total exports $\left(\mathrm{g} \mathrm{C} \mathrm{m}^{-2} \mathrm{yr}^{-1}\right)$ & 275 & 261 & 167 & 29 & 157 \\
Total respiration $\left(\mathrm{g} \mathrm{C} \mathrm{m}^{-2} \mathrm{yr}^{-1}\right)$ & 156 & 143 & 154 & 64 & 309 \\
Total throughput $\left(\mathrm{g} \mathrm{C} \mathrm{m}^{-2} \mathrm{yr}^{-1}\right)$ & 1365 & 1350 & 1035 & 520 & 2111 \\
Number of cycles & 12 & 12 & & 4 & 4 & 37 \\
Finn Cycling Index (\%) & 18 & 19 & 17 & 38 & 21 \\
\hline
\end{tabular}


tion). It has a theoretical basis: the Ockham razor, 'multiplicity ought not to be posited without necessity' (Legendre \& Legendre 1998). The principal consequences of this approach are: (1) the shortest pathway of carbon from one compartment to another is favoured $_{i}(2)$ when several pathways are of the same length, the solution is the most evenly distributed; (3) when an element is not required to satisfy the constraints of the system (through the equations and inequalities), it will disappear from the system (Niquil 1998). In practical terms this means that many flows can be underestimated or overestimated (those that exit the system quickly). Even if inverse analysis is an ideal means for obtaining new information about poorly defined systems, it still requires a good set of constraints. The substitution of data from other ecosystems to define some constraints can be an acceptable alternative to a lack of data. Sensitivity analyses then highlight the less reliable results and help to avoid unreasonable conclusions.

Despite the added constraints, some flows are still zero in the result of inverse analysis. This is due to the lack of data: when a flow is not necessary for the system of equations and inequalities, it is set to zero. For example, in our system there is no minimal constraint on the detritus input; thus, the method would have led to a positive inflow of material only if there had not been sufficient primary production to sustain the production in downstream flows. In addition, many of those downstream flows have reached the maximum values allowed by the constraints. Thus, the flows of detrital materials towards organisms other than bacteria was null. This was an unexpected result, as it had been assumed previously that detrital materials are consumed by macrofauna in non-negligible amounts (McLusky 1989, Mees \& Hamerlynck 1992, Azeitero \& Marques 1999, Mucha \& Costa 1999). In our system, each intermediate step between primary producers and predators is circumvented.

The network obtained here does not show pseudofaeces production; the results presented in this study are ingestion flows, and not consumption flows. Particle uptake and release as pseudo-faeces only slightly alters the particle composition, so that particles remain available to the other components of the ecosystem (Feuillet-Girard et al. 1994). The released fraction of consumed energy comprises between 62 and $92 \%$ (Héral et al. 1983, Deslous-Paoli et al. 1987, 1992, Soletchnick et al. 1996), of which 50 to $90 \%$ are pseudo-faeces (Deslous-Paoli et al. 1992, Soletchnik et al. 1993). However, these particles can enrich benthic exchanges in comparison to the pelagic ones. Pseudofaeces production by oysters has been evaluated in Feuillet-Girard et al. (1994). An inverse analysis computed with this data showed that an inclusion of the pseudo-faeces production obscures most of the other processes. Moreover, suspension feeders use pseudofaeces to enrich the organic fraction of their diet (Deslous-Paoli et al. 1992, Iglesias et al. 1992, Bayne et al. 1993, Barillé et al. 1997) and suspension feeding is a 'highly selective' process (Shumway et al. 1985, Graf \& Rosenberg 1997). For example, Crassostrea gigas feeds selectively upon the microphytobenthic food supply (Cognie et al. 2001) and the pearl oyster Pinctada margaritifera selects its prey on both size and taxonomic criteria (Loret et al. 2000). Considering that filter feeders may actively select living material for ingestion, the limited uptake of detritus in our results should be realistic.

The coupling between benthic and pelagic systems is strong in coastal habitats (Zeitzschel 1980, Niquil et al. 2001). Hydrodynamic processes play an important role in the MOB food web of molluscan assemblages (Sauriau et al. 1989, Gouleau et al. 2000). However, the Brouage mudflat is mainly a benthic system with regular tidal imports and exports of material to and from the water column. The small difference between the 2 benthic simulations obtained (Table 7) is largely due to the availability of reliable data on the ecosystem.

Coupling the benthic and pelagic subsystems means that the mudflat dynamics can be incorporated into models of the entire MOB. The Brouage system can be represented as a 'heart' that promotes the cycling of carbon (Fig. 8). External forcing provides for the supply of raw materials and the removal of detritus.

\section{Ecological properties}

Flows calculated by the model cannot be validated directly, but sensitivity analyses highlight the most responsive flows, and comparisons with other systems can be used to evaluate whether the order of magnitude of a computation is reasonable (Chardy \& Dauvin 1992).

Microphytobenthos dominates primary production

The microphytobenthos is the most important compartment of the system, in terms of activity (throughputs) and influence (sensitivity analyses), and its relative importance may be even higher, because phytoplankton production may have been overestimated in our study. The microphytobenthos influences the entire system as a determinant input from the bottom of the food web. This is a particularity of the Brouage ecosystem.

At Peck's Cove (Bay of Fundy, New Brunswick, Canada), Schwinghamer et al. (1986) calculated that 


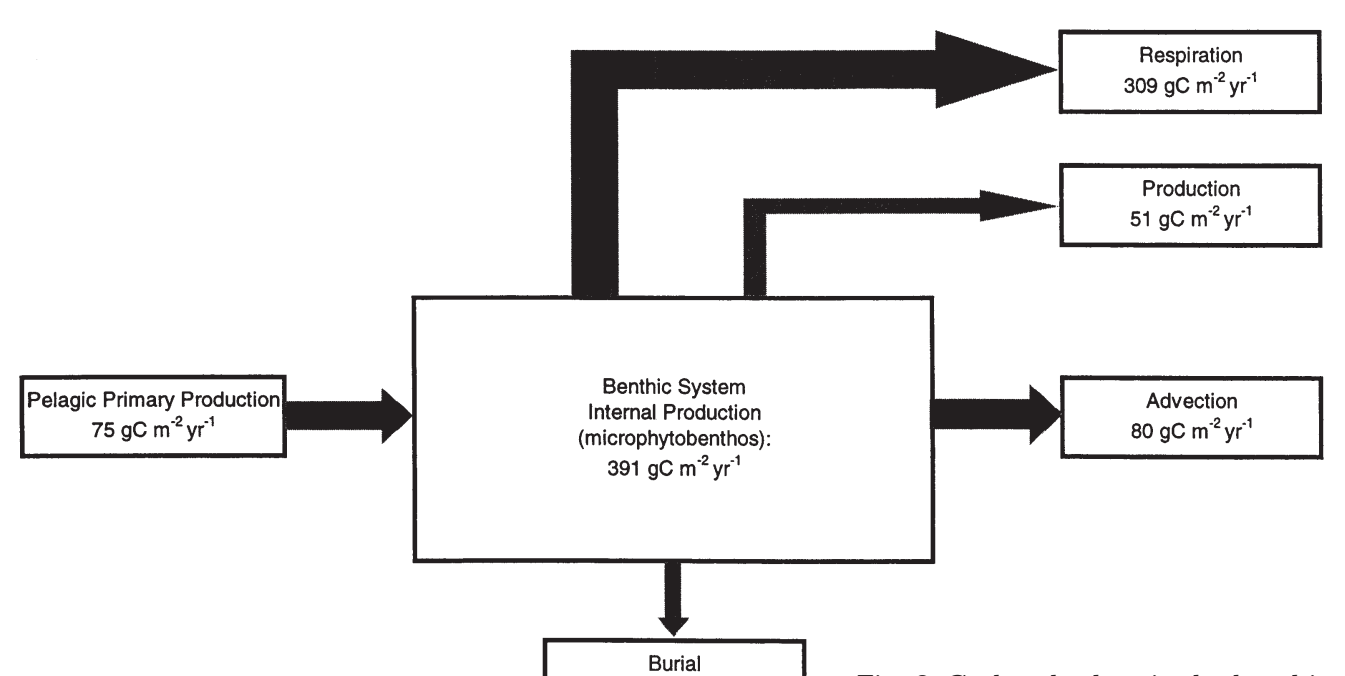

$26 \mathrm{gC} \mathrm{m}^{-2} \mathrm{yr}^{-1}$

Fig. 8. Carbon budget in the benthic system of the Brouage food web

the microalgal production of $778 \mathrm{kcal} \mathrm{m}^{-2} \mathrm{yr}^{-1}$ (58.5 $\mathrm{g} \mathrm{C} \mathrm{m}^{-2} \mathrm{yr}^{-1}$, Vollenveider 1965 in Rosenberg \& Loo 1983) was not sufficient to support the downstream production by other benthic organisms. An additional source of carbon was available from the fringing Spartina alterniflora in the Peck's Cove ecosystem. In comparison, on the mid-Atlantic coast of the US at Narragansett, Delaware, and Chesapeake Bay, Monaco \& Ulanowicz (1997) reported a net primary production of 403, 381, and $333 \mathrm{gC} \mathrm{m}^{-2}$ $\mathrm{yr}^{-1}$, respectively. Production is mostly phytoplankton; the Chesapeake Bay production is supplemented by the import of detrital material. In the western Wadden Sea an evaluation of primary production found that pelagic primary production dominated (microphytobenthic production was $118 \mathrm{gC} \mathrm{m}^{-2} \mathrm{yr}^{-1}$ ), whether evaluated with model calculations (Baretta \& Ruardij 1989) or field measurements (deWilde \& Beukema 1984 in Baretta \& Ruardij 1989). In the Bay of Saint Brieuc (France), primary production of the benthic system was estimated at $12 \mathrm{gC} \mathrm{m}^{-2} \mathrm{yr}^{-1}$ with a biomass of $1.6 \mathrm{~g} \mathrm{C} \mathrm{m}^{-2}$ (Chardy et al. 1993) using a nonlinear inverse model by Mercier 1986); the supply of detritus to the benthic system of Saint Brieuc Bay was $328 \mathrm{~g} \mathrm{C} \mathrm{m}^{-2} \mathrm{yr}^{-1}$, mostly through imports and pelagic primary production, raising the total food supply to $350 \mathrm{~g} \mathrm{C} \mathrm{m}^{-2} \mathrm{yr}^{-1}$, similar to that contributed by the microphytobenthos on the Brouage mudflat. In the Bay of Morlaix, France, Chardy \& Dauvin (1992) assessed phytoplankton production at 209, import of POC at 110, and microphytobenthic production at $10 \mathrm{gC} \mathrm{m}^{-2} \mathrm{yr}^{-1}$. The benthic systems of the bays of Saint Brieuc and Morlaix are typical detritusdominated systems. The Brouage ecosystem, however, is microphytobenthos-dominated; this is consistent with a comparison between Marennes-Oléron
Bay and 10 other coastal and estuarine ecosystems (Dame \& Prins 1998).

High throughput and cycling activity of meiofauna

Meiofauna represents $10 \%$ of total macrofaunal biomass, but its throughput is 1.6 times higher and its production is twice the macrofaunal production (including oysters); a similar observation has been made in other ecosystems. A 1967 study at Long Island showed that the metabolism of macrofauna accounted for only a small part of the oxygen uptake, and meiofauna and bacteria utilized the major portion of the energy consumed by the bottom ecosystem (Carey 1967 in Kuipers et al. 1981). In the western Wadden Sea, Kuipers et al. (1981) reported that a nematode had a weight specific metabolic rate 21 times higher than a macrobenthic individual. In the Bay of Saint Brieuc, Chardy et al. (1993) obtained an annual $\mathrm{P} / \mathrm{B}$ rate of $11 \mathrm{yr}^{-1}$ for the meiofauna, lower than our P/B rate of $31 \mathrm{yr}^{-1}$. In the Bay of Saint Brieuc, meiofauna and macrofauna production are equal, although the meiofauna is only $8 \%$ of the macrofauna biomass. In Morlaix Bay, Chardy \& Dauvin (1992) obtained a $\mathrm{P} / \mathrm{B}$ rate of $13.4 \mathrm{yr}^{-1}$, and a meiofauna production equivalent to the macrofauna production with $18 \%$ of its biomass.

The meiofauna in Brouage was initially thought to consist mostly of carnivorous species, thus constituting an isolated compartment. However, recent studies (Rzeznik pers. comm.) have shown that the fraction of carnivorous meiofauna is only $5 \%$, which implies that this compartment exchanges material with other compartments and the meiofauna have a role in system functioning. 
High throughput and cycling activities of bacteria

The biomass of pelagic bacteria at Brouage is unknown. Since the flows linked to this compartment have a significant influence on the result of the present computations, the model cannot be validated without additional measurements. Nonetheless, the relative activities of the benthic and pelagic bacterial compartments can be examined.

On the Brouage mudflat, benthic bacterial production is temperature dependent, and a wide range of values has been reported (Garet 1996). For example, benthic bacterial production can attain $3 \mathrm{~g} \mathrm{C} \mathrm{m}^{-2} \mathrm{~d}^{-1}$ in summer, compared to only $0.19 \mathrm{gC} \mathrm{m}^{-2} \mathrm{~d}^{-1}$ in winter (the lower boundary in our computations). In situ measurements of bacterial production are based on indirect measurements, and therefore values of bacterial production depend on the method and conversion factors used (Ducklow 2000 in Anderson \& Ducklow 2001). Thus, while benthic and pelagic bacteria were among the most active compartments, our model may still underestimate benthic bacterial activity on the mudflat.

The bacterial production/net primary production ratio (BP/NPP) is a normalized value of bacterial activity that can be compared with other ecosystems. In our system, the average value for BP/NPP was $38 \%$, higher than the values of 20 to $30 \%$ reported for pelagic systems (Cole et al. 1988 in Anderson \& Ducklow 2001). Schwingamer et al. (1986) found a BP/NPP ratio ranging from 25.5 to $257 \%$, depending on the number of active bacteria in the system, and Newell \& Linley 1984 gave a value of $19 \%$ for the English Channel.

In Saint Brieuc Bay the value of BP/benthic NPP obtained for the benthic system is $700 \%$ (calculated from Chardy et al. 1993), but there is also an input of phytoplankton and detritus from the water column, decreasing the adjusted value of BP/(imports+benthic $\mathrm{PP})$ to $12 \%$. Our value of $37 \%$ in the pelagic system is higher and is consistent with an important cycling of carbon in the bacterial compartment (Fig. 7).

Low cycling for an estuarine ecosystem

Baird et al. (1991) compared 6 marine ecosystems modelled as food webs with the same level of aggregation as we did on Brouage mudflat, and this allows a comparison of the 2 ecosystems (Wulff \& Ulanowicz 1989). The number of cycling pathways assessed for the Brouage system is high (37) compared to other estuaries and bays with 14 to 25 assessed pathways: Swarktops Estuary, 14; Ems estuary, 25; Chesapeake Bay, 20; Baltic Sea, 22. In upwelling systems, the number ranges from 1 (Benguela) to 15 (Peru) (Baird et al. 1991).

The Brouage system is less dependent upon recycling than other estuaries or bays, in spite of possessing various cycling pathways. The Finn Cycling Index $(\mathrm{FCI}=21 \%$, Table 7 ) is lower than in other estuaries or bays: Swarktops Estuary, 43.8; Ems Estuary, 28 (Baird et al. 1991); Delaware Bay, 37.3; Narragansett Bay, 48.2 (Monaco \& Ulanowicz 1997). The Brouage FCI value is higher in comparison to upwelling systems where the arrival of nutrients in large quantities makes recycling unimportant $(0.01 \%$ in Benguela, $3.2 \%$ in Peru). It is closer to those obtained in the Baltic Sea $(F C I=22 \%$, Baird et al. 1991 ) and Chesapeake Bay (FCI $=24.1 \%$, Monaco \& Ulanowicz 1997).

The 3 US mid-Atlantic estuaries compared by Monaco \& Ulanowicz (1997), Delaware Bay, Narragansett Bay, and Chesapeake Bay, were phytoplanktondominated, whereas the Brouage system is microphytobenthos dominated and the export of microphytobenthos to the water column is important. At Brouage the 'outwelling hypothesis' (Odum 1980) applies, i.e. the nutrients are not utilized in situ but exported to the surrounding region. In other words, the mudflat produces more material than can be degraded or stored within the system, and the surplus is exported to the Marennes-Oléron Bay and beyond.

\section{Production of the system}

The exports can be divided into 3 categories: unused primary production, detrital export, and secondary production. The system's production is characterized by material exported through the compartments: oyster commercial production, birds, and fish that exit the system.

The throughput of oysters is of the same order of magnitude as that of non-cultivated macrofauna, but the oyster compartment has more than twice the biomass (Fig. 2). Each of these compartments reaches maximal metabolic rates (the maximum rates allowed by the inequalities, Table 3), suggesting that they are not food limited. Competition for food resources between oysters and other macrofauna appears negligible in Brouage. The main competitors of oysters at Marennes-Oléron are Cerastoderma edule, Crepidula fornicata and Mytilus edulis (Sauriau 1987, Sauriau et al. 1989), all of which are rare at Brouage. However, oyster throughput represents $6.6 \%$ of the total primary production at Brouage, versus $7.9 \%$ for the rest of the macrofauna. The total macrofaunal activity $(16 \%$ of the total primary production) is not negligible. On Takapoto Atoll, where the pearl oyster Pinctada mar- 
garitifera is cultured, Niquil et al. (2001) evaluated this rate at $4.1 \%$ and thus considered that oyster farming was not food limited.

When evaluating the carrying capacity of the system, one must consider both phytoplanktonic and microphytobenthic production values. The primary production turnover time was computed to be $4.6 \mathrm{~d}$ at Brouage. This is still greater than the upper limit for productive ecosystems (4 d) suggested by Dame \& Prins (1998), but it is much smaller than the biomass/ throughput rates of oyster farms $(47 \mathrm{~d})$. The water residence time is short in MOB ( $<10$ d; Bacher 1989, Bacher et al. 1998), which allows a constant renewal of pelagic resources. Hence, for the Brouage system we assume that the flow arriving with each tide is renewed every $10 \mathrm{~d}$ on average, and consequently there is no food limitation for oysters or competition for food among the benthic macrofauna.

This result is paradoxical, since most earlier studies on carrying capacities (Héral et al. 1989, Bacher 1989, 1991, Raillard et al. 1993, Raillard \& Ménesguen 1994) showed an important density-dependence of oyster growth. Moreover, growth decreased in MOB when the biomass of trophic competitors of oysters was estimated to be $20 \%$ of oyster stocks (Sauriau 1987, Héral et al. 1989, Bacher 1991, Sauriau \& Bacher 1991, Sauriau et al. 1998). Thus the functioning of the entire MOB (of which Brouage is only a part), needs to be investigated to determine how fast food is exported from the mudflat, since the microphytobenthos contributes to the microalgal community in other parts of the Bay (Zurburg et al. 1994).

The major problem encountered in the evaluation of fish-related flows is methodological: it is very difficult to assess a moving population. At Brouage, the turbidity of the water does not permit visual detection, fish species live both on and off the mudflat, and the access area is too wide to allow interception-type studies, similar to those done in narrower channels, like in Mont Saint Michel (Lefeuvre et al. 1999).

As quantitative data on nekton uptake or production were not available for the Brouage mudflat, the nekton compartment has not been explicitly constrained. Our result appears high: the total throughput of nekton was $120 \mathrm{~g} \mathrm{C} \mathrm{m}^{-2} \mathrm{yr}^{-1}$, i.e. one quarter of the entire primary production. The main contributor to the nekton throughput was the microphytobenthos $\left(81 \mathrm{gC} \mathrm{m}^{-2} \mathrm{yr}^{-1}\right)$. Nekton consumption and production can be overestimated, because it is 1 of the 3 shortest exit pathways for microphytobenthos (the other 2 are phytoplankton and benthic detritus). One of the main nektonic species that feeds on microphytobenthos is the grey mullet Liza ramada, and its predation on the ecosystem has not, to our knowledge, been evaluated anywhere on the East Atlantic coast. In the US mid-Atlantic estuaries studied by Monaco \& Ulanowicz (1997), the fish compartment was divided into carnivorous and planktivorous fish, and grazing of benthic algae was not permitted.

Lafaille et al. (1998) estimated the contribution of fish communities to organic matter outflows from salt marshes into adjacent marine coastal waters at 0 to $10 \%$ in the Bay of Mont Saint Michel (France), far lower than our result of $29 \%$. One factor contributing to the difference between flow estimates is that the Mont Saint Michel Bay study site was accessible to the fish on $43 \%$ of the tidal cycles only. At Brouage the fish compartment is the next largest heterotrophic compartment after bacteria in terms of throughputs (Fig. 6); thus, validation of our estimate is crucial. Nonetheless, this flow does not have a significant influence on the values of flows that precede it (sensitivity analysis; data not shown); the material would just follow other pathways if we constrained it artificially. The flow from the nekton is another outflow of 'non-used microphytobenthos', such as the outflows from the phytoplankton and suspended detritus compartments. This is consistent with the outwelling concept (Odum 1980) evoked above.

Birds did not achieve the maximum consumption allowed by the model, although their prey did. The tight link between estuarine ecosystems and shorebirds (Baird \& Milne 1981) is confirmed here. The consumption efficiency of birds on the benthic macrofauna (consumption of birds/production of macrofauna) is $58 \%$. That is nearly 5 times higher than the value calculated in the Tagus Estuary (Portugal) where sea gulls were the most important predators (Moreira 1997). At the Brouage mudflat, gulls do not feed on the mudflat; this role is played by knots (Calidris canutus) and dunlins (C. alpina), which make up $68 \%$ of the total number of birds that forage on the mudflat. Moreira (1997) suggested that uptake of invertebrates by gulls in the Tagus estuary may have been overestimated because of their opportunistic diet, even though gulls do consume a significant percentage of invertebrates (Vernon 1972, Mudge \& Ferrus 1982, Curtis et al. 1985). In addition, gulls nip off the siphons of bivalves (Moreira 1997), reducing the impact on bivalve mortality because bivalves regenerate their siphons quickly (Hodgson 1982). In contrast to gulls, knots and dunlins consume M. balthica and other bivalves and snails whole (Zwarts \& Blomert 1992 and references therein). They prefer Macoma balthica, Nereis diversicolor and Corophium volutator, all of which are abundant on the Brouage mudflat (Kang 1999). Thus, the bird compartment is important in the Brouage mudflat food web. 


\section{CONCLUSIONS}

The Brouage mudflat sustains a high primary production dominated by microphytobenthos, and low carbon cycling. The competition for food is low at the herbivore level, but there is a risk of food depletion at higher predator level (nekton and birds), despite high meio- and macrofauna production. Validation of the model cannot be completed without further field investigations of the nekton population, pelagic bacterial and protozoan populations and metabolism, and pelagic primary production.

Coupling benthic and pelagic systems into the same computation yielded interesting results for the Brouage ecosystem, where the 2 systems are closely linked. This is a first step; the influence of the water column on the benthic system should be addressed on the scale of the entire bay to evaluate the impact of hydrodynamic phenomena on carbon flows and trophic level cycling in the ecosystem.

Appendix 1. Method of inverse analysis

The method is composed of 4 steps (Vézina \& Platt 1988): (1) Construct a conceptual model. Identify the groups of organisms (compartments) and specify the allowable flows of matter between them:

$$
\mathbf{F}=\left[\mathbf{f}_{1} \ldots \mathbf{f}_{\mathrm{i}} \ldots \mathbf{f}_{\mathrm{N}}\right]
$$

where $\mathbf{F}$ is the vector resulting from all possible flows; $\mathbf{f}$ is the vector of a single flow; and $\mathrm{N}$ is the number of all possible flows.

(2) Construct a linear system of equations that describes the relationships between flows. The following criteria must be met: (a) the flows into each compartment must balance the flows out of the compartment, because of the steady state assumption, and (b) measured flows provide complementary equations. The system of linear equations obtained can then be formulated as a matrix:

$$
[\mathbf{A}]_{\mathrm{b}, \mathrm{N}}[\mathbf{F}]_{\mathrm{N}, 1}=[\mathbf{B}]_{\mathrm{b}, 1}
$$

where $\mathbf{A}$ is the matrix of linear equations; $\mathrm{b}$ is the number of equations, characterised by $\mathrm{b}<\mathrm{N}$; and $\mathbf{B}$ is the matrix of solutions to the linear equations.

(3) Construct a set of constraints ( $\mathrm{h}$, inequalities). These ensure that all flows are positive, and constrain the assimilation efficiencies between observed minimal and maximal values, or any other rates used with observed biomasses (respiration, ingestion...).

$$
[\mathbf{G}]_{\mathrm{h}, \mathrm{N}}[\mathbf{F}]_{\mathrm{N}, 1}>[\mathbf{H}]_{\mathrm{h}, 1}
$$

where $\mathbf{G}$ is the matrix of linear inequalities; $h$ is the number of inequalities, characterised by $b+h<N$; and $B$ is the bounds of linear combinations of flows defined by $\mathbf{G}$.

(4) Impose the parsimony principle. This final condition ensures a unique solution; in other words, the chosen solution is the minimum of a norm.

\section{$\operatorname{Norm}(F)$ is minimal}

For more details on the solution of the equations see Vézina \& Platt (1988) and Vézina (1989).
Acknowledgements. This work was supported by a grant from IFREMER on fisheries and bivalve culture interactions under the scientific responsibility of N.N. We thank G. Blanchard, C. Dupuy and D. Fichet (LBEM La Rochelle), G. Boucher (UMR CNRS/MNHN), A. Bodoy, G. Claireaux, D. Degré, J. M. Guarini, P. Lafaille, F. Lagardère and P. Richard (CREMA l'Houmeau), A. Burd, G. A. Jackson and T. Richardson (Texas A\&M University), P. Chardy (LOB Arcachon), F. Corre (LPO Moëze), M. Héral and A. Nadeau (IFREMER), and F. E. Vauchez for data, ideas, criticism and advice. We also thank the anonymous reviewers for useful comments and suggestions.

\section{LITERATURE CITED}

Anderson TR, Ducklow HW (2001) Microbial loop carbon cycling in ocean environments studied using a simple steady-state model. Aquat Microb Ecol 26:37-49

Asmus H (1987) Secondary production of an intertidal mussel bed community related to its storage and turnover compartments. Mar Ecol Prog Ser 39:251-266

Asmus H, Asmus RM (1993) Phytoplankton-mussel bed interactions in intertidal ecosystems. NATO Adv Sci Series Vol G33

Azeitero UMM, Marques JC (1999) Temporal and spatial structure in the suprabenthic community of a shallow estuary (western Portugal: Mondego River estuary). Acta Oecol Int J Ecol 20(4):333-342

Bachelet G (1982) Quelques problèmes liés à l'estimation de la production secondaire. Cas des bivalves Macoma balthica et Scrobicularia plana. Oceanol Acta 5(4):421-431

Bacher C (1989) Capacité trophique du bassin de MarennesOléron: couplage d'un modèle de transport particulaire et d'un modèle de croissance de l'huître Crassostrea gigas. Aquat Living Resour 48:199-214

Bacher C (1991) Etude de l'impact du stock d'huitres et des mollusques compétiteurs sur les performances de croissance de Crassostrea gigas, à l'aide d'un modèle de croissance. ICES Mar Sci Symp 192:41-47

Bacher C, Duarte P, Ferreira JG, Héral M, Raillard O (1998) Assessment and comparison of the Marennes-Oléron Bay (France) and Carlingford Lough (Ireland) carrying capacity with ecosystem models. Aquat Ecol 31:379-394

Baird D, Milne H (1981) Energy flow in the Ythan Estuary, Aberdeenshire, Scotland. Estuar Coast Shelf Sci 13: $455-472$

Baird D, Evans PR, Milne H, Pienkowski MW (1985) Utilization by shorebirds of benthic invertebrate production in intertidal areas. Oceanogr Mar Biol Annu Rev 23: 573-597

Baird D, McGlade JM, Ulanowicz RE (1991) The comparative ecology of six marine ecosystems. Phil Trans R Soc Lond 333:15-29

Banse K, Mosher S (1980) Adult body mass and annual Production/biomass relationships of field populations. Ecol Monogr 50(3):355-379

Baretta JW, Ruardij P (1989) Carbon flow in the western Wadden Sea: model calculations. In: Ros JD (ed) Topics in marine biology. Sci Mar 53(2-3):523-529

Barillé L, Héral M, Barillé-Boyer AL (1997) Modélisation de l'écophysiologie de l'huître Crassostrea gigas dans un environnement estuarien. Aquat Living Resour 10:31-48

Bassoullet P, Le Hir P, Gouleau D, Robert S (2000) Sediment transport over an intertidal mudflat: field investigations and estimation of fluxes within the 'Baie de MarennesOléron' (France). Cont Shelf Res 20:1635-1653 
Bayne BL, Worrall CM (1980) Growth and production of mussels Mytilus edulis from two populations. Mar Ecol Prog Ser 3:317-328

Bayne BL, Hawkins AJS, Navarro E (1987) Feeding and digestion by the mussel Mytilus edulis L. (bivalvia: mollusca) in mixtures of silt and algal cells at low concentrations. J Exp Mar Biol Ecol 111:1-22

Bayne BL, Iglesias JIP, Hawkins AJS, Navarro E, Héral M, Deslous-Paoli JM (1993) Feeding behaviour of the mussel, Mytilus edulis: responses to variations in quantity and organic content. J Mar Biol Assoc UK 73:813-829

Beukema JJ, Cadée GC (1991) Growth rates of the bivalve Macoma balthica in the Wadden Sea during a period of eutrophication: relationships with concentrations of pelagic diatoms and flagellates. Mar Ecol Prog Ser 68: 249-256

Blanchard GF, Guarini JM, Richard P, Gros P (1997) Seasonal effect of the relationship between the photosynthetic capacity of intertidal microphytobenthos and temperature. J Phycol 33:723-728

Blanchard GF, Guarini JM, Bacher C, Huet V (1998) Contrôle de la dynamique à court terme du microphytobenthos intertidal par le cycle exondation-submersion. CR Acad Sci Paris 321:501-508

Blanchard GF, Guarini JM, Provot L, Richard P, Sauriau PG (2000) Measurement of ingestion rate of Hydrobia ulvae (Pennant) on intertidal epipelic microalgae: the effect of mud snail density. J Exp Mar Biol 255:247-260

Castel J, Labourg PJ, Escaravage V, Auby I, Garcia ME (1989) Influence of seagrass beds and oyster parks on the abundance and biomass patterns of meio- and macrobenthos in tidal flats. Estuar Coast Shelf Sci 28:71-85

Chambers MR, Milne H (1975) The production of Macoma balthica (L.) in theYthan estuary. Estuar Coast Mar Sci 3: 443-455

Chardy P, Dauvin JC (1992) Carbon flows in a subtidal fine sand community from the western English Channel: a simulation analysis. Mar Ecol Prog Ser 81:147-161

Chardy P, Gros P, Mercier H, Monbet Y (1993) Benthic carbon budget for the Bay of Saint Brieuc (Western Channel). Application of inverse method. Oceanol Acta 16:687-694

Cloern J (1987) Turbidity as a control on phytoplankton biomass and productivity in estuaries. Cont Shelf Res 7: $1367-1381$

Cognie B, Barillé L, Rincé Y (2001) Selective feeding of the oyster Crassostrea gigas fed on a natural microphytobenthos assemblage. Estuaries 24(1):126-131

Cranford PJ, Peer DL, Gordon DC (1985) Population dynamics and production of Macoma balthica in Cumberland Basin and Shepody Bay, Bay of Fundy. Neth J Sea Res 19: 135-146

Curtis DJ, Galbraith CG, Smyth JC, Thompson DBA (1985) Seasonal variations in prey selection by estuarine Blackheaded gulls. Estuar Coast Shelf Sci 21:75-89

Dame RF, Patten BC (1981) Analysis of energy flows in an intertidal oyster reef. Mar Ecol Prog Ser 5:115-124

Dame RF, Prins TC (1998) Bivalve carrying capacity in coastal ecosystems. Aquat Ecol 31:409-421

Deceunink B (1997) Plus de 2400000 oiseaux d'eau hivernants dénombrés en France à la mi-janvier 1996! Ornithos 5(1):12-17

Deceunink B, Mahéo R (1998) Limicoles de l'enquête nationale 1995-1996 et évolution des populations sur 12 ans. Ornithos 5:97-117

Dechambenoy CL, Pontier F, Sirou F, Vouvé J (1977) Apport de la thermographie infrarouge aéroportée à la connaissance de la dynamique superficielle des estuaires (sys- tème Charente-Seudre-Anse de l'Aiguillon). CR Acad Sci Paris Sér D 284:1269-1272

Desholm M (2000) The relationship between the number of staging dunlins Calidris alpina and the abundance of their benthic prey: the effect of severe winters. Dan Ornitol Foren Tidsskr 94:19-28

Deslous-Paoli JM, Héral M, Masse H (1983) Bilan énergétique d'une population naturelle de Crepidula fornicata (L.) dans le bassin de Marennes-Oléron. In: IFREMER et CNRS Pirocéan (eds) Bases biologiques de l'aquaculture. Actes de colloques, Vol 1. IFREMER, Montepellier, p 109-124

Deslous-Paoli JM, Sornin JM, Héral M (1987) Variations saisonnières in situ de la production et de la composition de trois mollusques estuariens (Mytilus edulis, Crassostrea gigas, Crepidula fornicata). Haliotis $16: 223-245$

Deslous-Paoli JM, Boromthanarat S, Héral M, Boromthanarat W, Razet D (1990) Energy budget of a Mytilus edulis L. population during its first year on bouchots in the Bay of Marennes-Oléron. Aquaculture 91:49-63

Deslous-Paoli JM, Lannou AM, Geairon P, Bougrier S, Raillard O, Héral M (1992) Effect of the feeding behaviour of Crassostrea gigas on biosedimentation of natural particulate matter. Hydrobiologia 231:85-91

Desprez M, Bachelet G, Beukema JJ, Ducrotoy JP and 5 others (1991) Dynamique des populations de Macoma balthica (L.) dans les estuaires du Nord-ouest de l'Europe: Premiere synthese. In: Elliott M, Ducrotoy JP (eds ) Estuaries and coasts: spatial and temporal intercomparisons. Olsen \& Olsen Int Symp Ser, Fredensborg, p 159-166

Dupuy C, Bel Hassen M, Le Gall S (1999) Protists as a trophic link between picocyanobacteria and the filter-feeding bivalve Crassostrea gigas. Bull Inst Océanogr 19:533-540

Dupuy C, Pastoureau A, Ryckaert M, Sauriau PG, Montanié H (2000) Impact of the oyster Crassostrea gigas on a microbial community in Atlantic coastal ponds near La Rochelle. Aquat Microb Ecol 22:227-242

Essink K, Beukema JJ, Coosen J, Craeymeersch JA, Ducrotoy JP, Michaelis H (1991) Population dynamics of the bivalve mollusc Scrobicularia plana da Costa: comparisons in time and space. In: Elliott M, Ducrotoy JP (eds) Estuaries and coasts: spatial and temporal intercomparisons Olsen \& Olsen Int Symp Ser, Fredensborg, p 167-172

Fasham MJR (1985) Flow analysis of material in the marine euphotic zone. In: Ulanowicz RE, Platt T (eds) Ecosystem theory for biological oceanography. Can Bull Fish Aquat Sci 213:139-162

Feuillet-Girard M, Héral M, Abrioux MF, Fontugne M (1994) Carbone organique dissous et particulaire de la colonne d'eau et de l'interface eau-sédiment du bassin de MarennesOléron: influence des huîtres. Oceanol Acta 17(3):271-284

Fichez R, Jickells TD, Edmunds HM (1992) Algal blooms in high turbidity, a result of the conflicting consequences of turbulence on nutrient cycling in a shallow water estuary. Estuar Coast Shelf Sci 35:577-592

Finn J (1976) Measure of ecosystem structure and function derived from the analysis of flows. J Theor Biol 56:363-380

Francesch O, Lopez Jamar E (1991) Dynamics, growth and production of Abra Alba and Abra Nitida from the La Coruna, NW of Spain. Bol Inst Esp Oceanogr 7(2):101-113

Fuhrman JA, Azham F (1982) Thymidine incorporation as a measure of heterotrophic bacterioplankton production in marine surface waters: evaluation and field results. Mar Biol 66:109-120

Garet MJ (1996) Transformation bactérienne de la matière organique dans les sédiments côtiers. Relation entre les métabolismes respiratoires et les activités exoprotéolytiques bactériennes. PhD thesis, University of Bordeaux II 
Gerdol V, Hughes RG (1994) Feeding behaviour and diet of Corophium volutator in an estuary in south eastern England. Mar Ecol Prog Ser 114:103-108

Gerlach SA (1971) On the importance of meiofauna for benthos communities. Oecologia 6:176-190

Giere O (1993) Meiobenthology, the microscopic fauna in aquatic sediments. Springer-Verlag, Berlin

Goss-Custard JD, Jones RE, Newbery PE (1977) The ecology of the Wash I. Distribution and diet of wading birds (Charadrii). J Appl Ecol 14:681-700

Gouleau D, Jouanneau JM, Weber O, Sauriau PG (2000) Short- and long-term sedimentation on MontportailBrouage intertidal mudflat, Marennes-Oléron Bay, France. Cont Shelf Res 20:1513-1530

Goulletquer P, Héral M (1997) Marine Molluscan production trends in France: from fisheries to aquaculture. In: MacKenzie CL, Hobart W, Kennedy V (eds) The history, present condition and future of the molluscan fisheries of North and Central America and Europe. NOAA Tech Rep NMFS 129:137-164

Graf G, Rosenberg R (1997) Bioresuspension and Biodeposition, a review. J Mar Syst 11:269-278

Guarini JM, Blanchard GF, Bacher C, Gros P and 5 others (1998) Dynamics of spatial patterns of microphytobenthic biomass: inferences from a geostatistical analysis of two comprehensive surveys in Marennes-Oléron Bay (France). Mar Ecol Prog Ser 166:131-141

Guarini JM, Gros P, Blanchard GF, Bacher C (1999) La dynamique à court terme de la biomasse du microphytobenthos intertidal. Formalisation mathématique. CR Acad Sci Paris 322:363-373

Guarini JM, Blanchard GF, Gros P, Gouleau D, Bacher C (2000) Dynamic model of the short-term variability of microphytobenthic biomass on temperate intertidal mudflats. Mar Ecol Prog Ser 195:291-303

Guérault D, Désaunay Y (2001) Peuplement halieutique et nourricerie dans les secteurs d'expérimentation del'ostréiculture en eau profonde dans le pertuis d'Antioche. Revue Interne, DRV/RV/ECOHAL, Direction des Resources Vivantes, IFREMER, Nantes

Guérault D, Dorel D, Désaunay Y (1996) Cartographie des nourriceries littorales de poissons du Golfe de Gascogne. MAPA MAP, IFREMER, Nantes

Guillou J, Bachelet G, Desprez M, Ducrotoy JP and 6 others (1990) Les modalités de la reproduction de la coque (Cerastoderme edule) sur le littoral français de la Manche et de l'Atlantique. Aquat Living Resour 3:29-41

Haney J, Jackson G (1996) Modelling phytoplankton growth rates. J Plankton Res 18:63-85

Hawkins AJS, Navarro E, Iglesias JIP (1990) Comparative allometries of gut-passage time, gut content and metabolic faecal loss in Mytilus edulis and Cerastoderma edule. Mar Biol 105:197-204

Hawkins AJS, Smith RFM, Bayne BL, Héral M (1996) Novel observations underlying the fast growth of suspensionfeeding shellfish in turbid environments: Mytilus edulis. Mar Ecol Prog Ser 131:179-190

Hawkins AJS, Bayne BL, Bougrier S, Héral M, Iglesias JIP, Navarro E, Smith RFM, Urrutia MB (1998) Some general relationships in comparing the feeding physiology of suspension-feeding bivalve molluscs. J Exp Mar Biol Ecol 219:87-103

Hawkins CM (1985) Population carbon budgets and the importance of the amphipode Corophium volutator in the carbon transfer on a Cumberland basin mudflat, upper Bay of Fundy, Canada. Neth J Sea Res 19(2):165-176

Héral M, Deslous-Paoli JM, Sornin JM (1983) Transferts énergétiques entre l'huître Crassostrea gigas et la nourriture potentielle disponible dans un bassin ostréicole: premières approches. Oceanis 9(3):169-194

Héral M, Bacher C, Deslous-Paoli JM (1989) La capacité trophique des bassins ostréicoles. In: Troadec JP (ed) L'homme et les ressources halieutiques. IFREMER, Brest, p 225-259

Hily C (1976) Peuplement benthique des Pertuis Charentais. $\mathrm{PhD}$ thesis, University of Western Britanny, Brest

Hodgson AN (1982) Studies on wound healing, and an estimation of the rate of regeneration, of the siphon of Scrobicularia plana (da Costa). J Exp Mar Biol Ecol 62:117-128

Iglesias JIP, Navarro E, Alvarez Jorna P, Armentina I (1992) Feeding particle selection and absorption in cockles Cerastoderma edule (L.) exposed to variable conditions of food concentration and quality. J Exp Mar Biol Ecol 162: 177-198

Joint I, Pomroy A (1981) Primary production in a turbid estuary. Estuar Coast Shelf Sci 13:303-316

Joint I, Pomroy A (1993) Phytoplankton biomass and production in the southern North Sea. Mar Ecol Prog Ser 99: 169-182

Kang CK (1999) Structures trophiques et production secondaire dans les réseaux benthiques intertidaux du bassin de Marennes-Oléron: utilisation du traçage isotopique naturel. $\mathrm{PhD}$ thesis, University of Nantes

Kuipers BR, de Wilde PAWJ, Creuzberg F (1981) Energy flow in a tidal flat ecosystem. Mar Ecol Prog Ser 5:215-221

Lafaille P, Brosse S, Feuteun E, Baisez A, Lefeuvre JC (1998) Role of fish communities in particulate organic matter fluxes between salt marshes and coastal marine waters in the Mont Saint-Michel Bay. Hydrobiologia 373/374: 121-133

Langdon CJ, Newell RIE (1990) Utilization of detritus and bacteria by two bivalve suspension-feeders, the oyster Crassostrea virginica and the mussel Geukensia demissa. Mar Ecol Prog Ser 58:299-310

Le Dréan-Quénec'hdu S, Mahéo R (1997) Les limicoles séjournant dans les traicts du Croisic (presqu'île guérandaise, Loire-Atlantique): régime alimentaire et impact sur les populations de mollusques bivalves. Alauda 65(2): 131-149

Lefeuvre JC, Lafaille P, Feunteun E (1999) Do fish communities function as biotic vectors of organic matter between salt marshes and marine coastal waters? Aquat Ecol 33: 293-299

Le Gall S, Bel Hassen M, Le Gall P (1997) Ingestion of a bactivorous ciliate by the oyster Crassostrea gigas: protozoa as a trophic link between picoplankton and benthic suspension feeders. Mar Ecol Prog Ser 152:301-306

Legendre P, Legendre L (1998) Numerical ecology, 2nd edn. Elsevier, Oxford

Le Hir P, Roberts W, Cazaillet O, Christie M, Bassoullet $\mathrm{P}_{\mathrm{r}}$ Bacher C (2000) Characterization of intertidal flat hydrodynamics. Cont Shelf Res 20:1433-1459

Linley EAS, Newell RC, Lucas MI (1983) Quantitative relationships between phytoplankton, bacteria and heterotrophic microflagellates in shelf waters. Mar Ecol Prog Ser 12:77-89

Loret P, Pastoureaud A, Bacher C, Delesalle B (2000) Phytoplankton composition and selective feeding of the pearl oyster Pinctada margaritifera in the Takapoto lagoon (French Polynesia): in situ study using optical microscopy and HPLC pigment analysis. Mar Ecol Prog Ser 199:55-67

McLusky DS (1989) The estuarine ecosystem, 2nd edn. Chapman \& Hall, New York

Medernach L, Grémare A (1999) Comparaison de méthodes 
d'évaluation de la production secondaire d'une population de l'annélide polychète Ditrupa arietina (O. F. Muller). Oceanol Acta 22(3):337-352

Mees J, Hamerlynck O (1992) Spatial community structure of the winter hyperbenthos of the Schelde-estuary, The Netherlands, and adjacent coastal waters. Neth J Sea Res 29:357-370

Ménesguen A, Hoch T (1997) Modelling the biogeochemical cycles of elements limiting primary production in the English Channel. I. Role of thermohaline stratification. Mar Ecol Prog Ser 146:173-188

Mercier H (1986) Determining the general circulation of the ocean: a non linear inverse problem. J Geophys Res 91: 5103-5109

Monaco ME, Ulanowicz RE (1997) Comparative ecosystem trophic structure of three US mid-Atlantic estuaries. Mar Ecol Prog Ser 161:239-254

Montagna PA, Blanchard GF, Dinet A (1995) Effects of production and biomass of intertidal microphytobenthos on meiofaunal grazing rates. J Exp Mar Biol Ecol 185:149-165

Moreira F (1996) Diet and feeding behaviour of grey plovers Pluvialis squatarola and redshanks Tringa totanus in a southern European estuary. Ardeola 43(2):145-156

Moreira F (1997) The importance of shorebirds to energy fluxes in a food web of a south European estuary. Estuar Coast Shelf Sci 44:67-78

Mucha AP, Costa MH (1999) Macrozoobenthic community structure in two Portuguese estuaries: relationship with organic enrichment and nutrient gradients. Acta Oecol Int J Ecol 20(4):363-376

Mudge GP, Ferrus PN (1982) The feeding ecology of five species of gulls (aves: Larini) in the inner Bristol Channel. J Zool Lond 197:497-510

Newell RC, Field JG (1983) The contribution of bacteria and detritus to carbon and nitrogen flow in a benthic community. Mar Biol Lett 4:23-36

Newell RC, Linley EAS (1984) Significance of microheterotrophs in the decomposition of phytoplankton: estimates of carbon and nitrogen flow based on the biomass of plankton communities. Mar Ecol Prog Ser 16:105-119

Niquil N (1998) Etude par la modélisation du fonctionnement et de la stabilité du réseau trophique planctonique d'un lagon d'atoll (Takapoto, Polynésie Française). PhD thesis, University of Perpignan

Niquil N, Pouvreau S, Sakka A, Legendre L, Addessi L, LeBorgne R, Charpy L, Delesalle B (2001) Trophic web and carrying capacity in a pearl oyster farming lagoon (Takapoto, French Polynesia). Aquat Living Resour 14: 165-174

Odum EP (1980) The status of three ecosystem-level hypotheses regarding salt marsh estuaries: tidal subsidy, outwelling and detritus-based food chains. In: Kennedy VS (ed) Estuarine perspectives. Academic Press, London, p 485-495

Pace ML, Glasser JE, Pomeroy LR (1984) A simulation analysis of continental shelf food webs. Mar Biol 82:47-63

Piersma T, Davidson NC (1992a) The migration of knots. Water Study Group Bull 64(Suppl):1-29

Piersma T, Davidson NC (1992b) The migration and annual cycles of five subspecies of knots in perspective. Water Study Group Bull 64(Suppl):187-197

Pigeot J, Miramand P, Garcia-Meunier P, Guyot T, Séguignes M (2000) Présence d'un nouveau prédateur de l'huître creuse, Ocinebrellus inornatus (Récluz, 1851), dans le bassin conchylicole de Marennes-Oléron. CR Acad Sci Paris 323:697-703

Raffaeli D, Conacher A, McLahan H, Emes C (1989) The role of epibenthic crustacean predators in an estuarine food web. Estuar Coast Shelf Sci 28:149-160

Raillard O, Ménesguen A (1994) An ecosystem box model for estimating the carrying capacity of a macrotidal shellfish system. Mar Ecol Prog Ser 115:117-130

Raillard O, Deslous-Paoli JM, Héral M, Razet D (1993) Modelling growth and feeding of the Japanese oyster Crassostrea gigas in Marennes-Oléron Bay (France). Oceanol Acta 16:73-82

Ravail B, Héral M, Maestrini S, Robert JM (1988) Incidence de la Charente sur la capacité trophique du bassin ostréicole de Marennes-Oléron. J Rech Océanogr 13(1-2):48-52

Riera P, Richard P (1997) Temporal variations of $\delta^{13} \mathrm{C}$ in particulate organic matter and oyster Crassostrea gigas in Marennes-Oléron Bay (France): effect of freshwater inflow. Mar Ecol Prog Ser 147:105-115

Riisgard HU (1991) Suspension feeding in the polychaete Nereis diversicolor. Mar Ecol Prog Ser 70:29-37

Rosenberg R, Loo LO (1983) Energy-flow in a Mytilus edulis culture in western Sweden. Aquaculture 35:151-161

Sauriau PG (1987) Les mollusques noncultivés du bassin de Marennes-Oléron: quantification et répartition géographique des stocks. Haliotis 16:527-541

Sauriau PG, Bacher C (1991) Cartographie krigée des mollusques suspensivores competiteurs trophiques des huîtres du bassin de Marennes-Oléron: implications pour la planification de l'échantillonnage. J Rech Océanogr 16(1-2):1-4

Sauriau PG, Mouret V, Rincé JP (1989) Organisation trophique de la malacofaune benthique non cultivée du bassin ostréicole de Marennes-Oléron. Oceanol Acta 12(2): 193-204

Sauriau PG, Pichocki-Seyfried C, Walker P, De Montaudouin X, Palud C, Héral M (1998) Crepidula fornicata L. (mollusque, gastéropode) en baie de Marennes-Oléron: cartographie des fonds par sonar à balayage latéral et estimation du stock. Oceanol Acta 21(2):353-362

Sautour B, Castel J (1993a) Distribution of zooplankton populations in Marennes-Oléron Bay (France), structure and grazing impact of copepod communities. Oceanol Acta 16(3):279-290

Sautour B, Castel J (1993b) Feeding behaviour of the coastal copepod Euterpina acutifrons on small particles. Cah Biol Mar 34:239-251

Sautour B, Castel J (1998) Importance of microzooplanktonic crustaceans in the coastal food chain: Bay of MarennesOléron, France. Oceanol Acta 21(1):105-112

Schwinghamer P, Hargrave B, Peer D, Hawkins CM (1986) Partitioning of production and respiration among size groups of organisms in an intertidal benthic community. Mar Ecol Prog Ser 31:131-142

Shaw P, Purdie DA (2001) Phytoplankton photosynthesisirradiance parameters in the near-shore UK coastal waters of the North Sea: temporal variation and environmental control. Mar Ecol Prog Ser 216:83-94

Shumway SE, Cucci TL, Newell RC, Yentsch CM (1985) Particle selection, ingestion, and absorption in filter feeding bivalves. J Exp Mar Biol Ecol 91:77-92

Soletchnik P, Héral M, Razet D, Bougrier S, Geairon P (1993) Bilan énergétique de l'huître creuse (Crassotrea gigas) durant la période de forte croissance en baie de Marennes-Oléron, France. Int Council Explor Sea C.M. 1993/K:40

Soletchnik P, Goulletquer P, Héral M, Razet D, Geairon P (1996) Evaluation du bilan énergétique de l'huitre creuse Crassostrea gigas, en baie de Marennes-Oléron (France). Aquat Living Resour 9:65-73

Soletchnik P, Faury N, Razet D, Goulletquer P (1998) Hydro- 
biology of the Marennes-Oléron Bay. Seasonal indices and analysis of trends from 1978 to 1995. Hydrobiologia 386:131-146

Sornin JM, Delmas D, Deslous-Paoli JM (1987) Evolutions quantitatives et qualitatives du seston dans une claire à huîtres : relation avec la sédimentation et la biodéposition. Océanis 13(4-5):531-541

Sukhotin AA (1992) Respiration and energetics in mussels (Mytilus edulis L.) in the White Sea. Aquaculture 101: 41-57

Turpie JK, Hockey PAR (1996) Foraging ecology and seasonal energy budgets of estuarine grey plovers Pluvialis squatarola and whimbrels Numenius phaeopus at the southern tip of Africa. Adea 84 (1/2):57-74

Ulanowicz RE (1986) Growth and development. SpringerVerlag, New York

Ulanowicz RE (1997) Ecology, the ascendant perspective. In: Allen TFH, Roberts DW (eds) Complexity in ecological system series. Columbia University Press, New York

Vernon JDR (1972) Feeding habitats and food of the Blackheaded and common gulls. Part 2-food. Bird study 19: 173-184

Vézina AF (1989) Construction of flow networks using inverse methods. In: Wulff F, Field JG, Mann KH (eds) Network analysis in marine ecology: methods and applications.

Editorial responsibility: Otto Kinne (Editor),

Oldendorf/Luhe, Germany
Coastal and marine studies, Vol 32. Springer-Verlag, Berlin, p 62-81

Vézina AF, Pace ML (1994) An inverse model analysis of planktonic food webs in experimental lakes. Can J Fish Aquat Sci 51:2034-2044

Vézina AF, Platt T (1988) Food web dynamics in the ocean. I. Best estimates using inverse methods. Mar Ecol Prog Ser 42:269-287

Warwick RM, Price R (1975) Macrofauna production in an estuarine mudflat. J Mar Biol Assoc UK 55:1-18

Wulff F, Ulanowicz RE (1989) A comparative anatomy of the Baltic Sea and Chesapeake Bay ecosystems. In: Wulff $F_{1}$ Field JG, Mann KH (eds) Network analysis in marine ecology: methods and applications. Coastal and marine studies, Vol 32. Springer-Verlag, Berlin, p 232-256

Zeitzschel B (1980) Sediment-water interactions in nutrient dynamics. In: Coull TC, Tenore KR (ed) Marine benthic dynamics. University of South Carolina Press, Columbia, SC, p 195-218

Zurburg W, Smaal A, Héral M, Dankers N (1994) Seston dynamics and bivalve feeding in the Bay of MarennesOléron (France). Neth J Aquat Ecol 26(3-4):459-466

Zwarts L, Blomert AM (1992) Why knots Calidris canutus take medium-sized Macoma balthica when six prey species are available. Mar Ecol Prog Ser 83:113-128

Submitted: April 3, 2002; Accepted: July 26, 2002

Proofs received from author(s): December 9, 2002 